\title{
Punk, Politics and British (fan)zines, 1974- 84:'While the world was dying, did you wonder why?
}

Article

Accepted Version

Worley, M. (2015) Punk, Politics and British (fan)zines, 197484:'While the world was dying, did you wonder why? History Workshop Journal, 79 (1). pp. 76-106. ISSN 0309-2984 doi: https://doi.org/10.1093/hwj/dbu043 Available at https://centaur.reading.ac.uk/39957/

It is advisable to refer to the publisher's version if you intend to cite from the work. See Guidance on citing.

Published version at: http://hwj.oxfordjournals.org/content/current

To link to this article DOI: http://dx.doi.org/10.1093/hwj/dbu043

Publisher: Oxford University Press

All outputs in CentAUR are protected by Intellectual Property Rights law, including copyright law. Copyright and IPR is retained by the creators or other copyright holders. Terms and conditions for use of this material are defined in the End User Agreement.

www.reading.ac.uk/centaur 
Central Archive at the University of Reading

Reading's research outputs online 


\title{
'While the world was dying, did you wonder why?':
}

\section{Punk, Politics and British (fan)zines, 1976-84}

\author{
Matthew Worley
}

\begin{abstract}
This article recovers and contextualizes the politics of British punk fanzines produced in the late 1970s and early 1980s. It argues that fanzines - and youth cultures more generally - serve to provide a contested cultural space for young people to express their ideas, opinions and anxieties. Simultaneously, it maintains that punk fanzines offer the historian a portal into a period of significant socio-economic, political and cultural change. As well as presenting alternative cultural narratives to the formulaic accounts of punk and popular music now common in the mainstream media, fanzines allow us a glimpse of the often radical ideas held by a youthful milieu rarely given expression in the political arena.
\end{abstract}

Music fanzines started out as a way of putting forward the views of music lovers that the big music press didn't recognise. Now we still use the name although some fanzines have very little to do with music, but use the idea to publish other arts and ideas [...] The fact is that anybody with something to say or wanting some outlet for their art can start a 'fanzine', even if it's only a one off consisting of two pages. Community presses are the cheapest and beter [sic] badges, rough trade along with local record shops etc. will distribute it. So why not do it?

Paper Alcohol Collective (Northampton) ${ }^{1}$

Produced in the summer of 1976, the first issue of Sniffin' Glue ... and Other Rock ' $n$ ' Roll Habits does not now look like a portent of cultural change (see figure 1). Cheaply photocopied on eight sides of A4 paper and stapled in the top-left corner, the title is scribbled in black felt-tip pen beneath which a typed strap-line comments: 'This thing is not meant to be read ... it's for soaking in glue and sniffin'. The contents are scrawled over the

\footnotetext{
${ }^{1}$ Editorial to Do You Know Vanessa Redgrave?, No. 2, 1981, p. 2. The title of this article comes from Kill Your Pet Puppy, No. 2, 1980, p. 4.
} 
cover page: The Ramones, Blue Oyster Cult, 'punk reviews'. Inside, the same combination of pen and type outline the magazine's rationale: 'We believe rock ' $n$ ' roll, especially "punk rock", is about enjoyment and nothing else - leave the concepts to the likes of Yes, Mike Oldfield etc.' A series of breathless record and gig reviews then follow, before the last page reveals a little more cultural context. ${ }^{2}$ First, the weekly British music press - which in 1976 comprised Melody Maker, New Musical Express (NME), Record Mirror and Sounds - is dismissed as being 'so far away from the kids that they can't possibly say anything of any importance to punk rock fans'. ${ }^{3}$ Second, 'punk rock' itself is given definition. Although the term formed part of the music press' lexicon by the early 1970s, it had only just been adopted to describe a new wave of bands committed to what Sniffin' Glue characterized as 'rock in its lowest form - on the level of the streets. Kids jamming together in the dad's garage, poor equipment, tight clothes, empty heads (nothing to do now you've left school) and model shops'. ${ }^{4}$ Third, 'most' contemporary British rock groups are described as 'past it', with only a few fledgling bands - including the Sex Pistols - noted for providing any sense of excitement. Finally, the fanzine's editor, Mark P [Mark Perry], a teenage bank clerk from Deptford, delivers the first of what would become a series of rallying cries for those reading Sniffin' Glue to build a punk scene themselves; to 'do it yourself'. 'All you kids', he urged more definitively in issue 5 (November 1976), 'don't be satisfied with what we write. Go out and start your own fanzines [...] flood the market with punk writing' ${ }^{5}$

\footnotetext{
${ }^{2}$ Mark Perry, 'The Last Page', Sniffin Glue, No. 1, 1976, p. 8.

${ }^{3}$ The rationale for this was the unsympathetic coverage given to The Ramones' first visit to London in the summer of 1976.

${ }^{4}$ The earliest use of 'punk' in such a context came with the journalism of Lester Bangs, Dave Marsh and Mike Saunders, before Lenny Kaye's 1972 sleevenotes to Nuggets (Elektra, 1972), a compilation of mid-1960s garage bands, helped cement the term in relation to rock music stripped down to its bare essentials and imbued with an irreverent 'teenage' attitude. Thereafter, the US magazine Punk, produced by Legs McNeil and John Holmstrom from January 1976, helped connect 1960s garage bands with the approach and attitude of The Stooges, MC5, Lou Reed and New York bands such as The Dictators and The Ramones.

${ }^{5}$ Mark Perry, 'No Doubt About It ...', Sniffin Glue, No. 5, 1976, p. 2.
} 


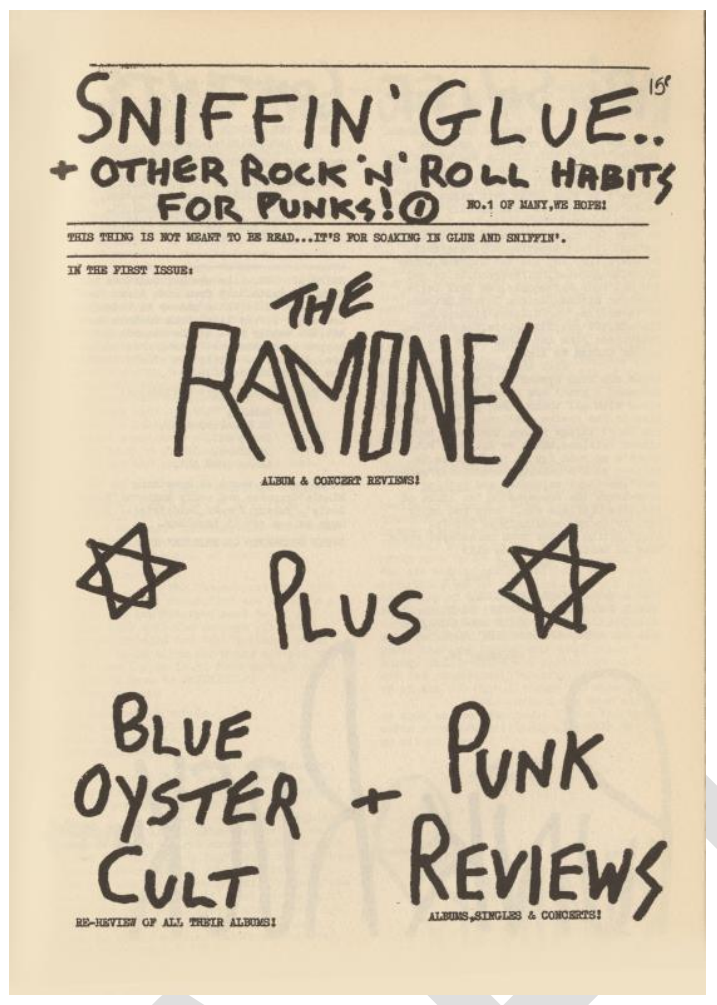

As is well known, the period between Sniffin' Glue's appearance in July 1976 and its final issue in August-September 1977 marked the emergence of punk as a recognizable musical form and youth culture. ${ }^{6}$ Integral to this was the production of countless fanzines inspired by Perry's lead and the DIY ethos that underpinned British punk almost from the outset. Across the UK, fanzines helped initiate, encourage and survey the upsurge of activity sparked by the Sex Pistols, The Clash and others. From Cumbernauld, near Glasgow, Ripped \& Torn appeared in late 1976, billed as the 'first Scottish punk mag., written by fans ... for fans'. ${ }^{7}$ This was followed by A Boring Fanzine, Trash '77 (both Glasgow), Edinburgh's Hangin' Around, Jungleland and titles such as Crash Bang (Airdrie), Granite City (Aberdeen), Kingdom Come (Dunfermline) and The Next Big Thing (Stirlingshire). In Manchester, early fanzines included Ghast Up, Girl Trouble, Noisy People, Plaything and Shy Talk; the Sheffield scene was covered by Gun Rubber, Home Groan and Submission. The emergence of Birmingham

\footnotetext{
${ }^{6}$ The best account of British punk's emergence remains Jon Savage, England's Dreaming: Sex Pistols and Punk Rock, London: Faber \& Faber, 1991.

${ }^{7}$ Ripped \& Torn, No. 1, 1976, p. 1.
} 
punk was captured by Censored; Leeds by New Pose and Pure Mania; Bristol by Loaded. Alternative Ulster and Private World reported from Northern Ireland; Heat and Raw Power set up in Dublin; Rip Off and Up Yours in Wales. Back in England, Bombsite committed to 'fight for the new wave in the north west ${ }^{\prime}{ }^{8}$, while events in the north east were detailed in Bored Stiff, Deviation Street, Gabba Gabba Hey, Garage Land, Genocide and Out Now. In and around London, meanwhile, multiple fanzines were produced over 1976-77, including 48 Thrills, Bondage, Chainsaw, In the City, Jamming, Jolt, Live Wire, London's Outrage, Panache, Sideburns, Skum and White Stuff. ${ }^{9}$

Many of these - alongside various other titles produced throughout Britain's towns, cities and villages ${ }^{10}$ - followed the Sniffin' Glue template: fervid text with cut ' $n$ ' paste imagery that was Xeroxed and sold at minimal cost at gigs or in local record shops. ${ }^{11}$ Most lasted for but a handful of issues, printed in runs of tens or a few hundred. Several were one-offs created in a flurry of excitement or inspiration. Some, however, began to develop beyond the rather crude efforts of the first punk 'zines towards more diverse and creative content and design. Sniffin' Glue itself evolved over 1976-77 to include critical analyses of punk's development, photographs and contributions from others beside Perry. London's

\footnotetext{
${ }^{8}$ Bombsite, No. 2, 1977, p. 2.

${ }^{9}$ Other London, or near-London, titles from 1976-77 include: Cells, City Chains, Cliché, Fair Dukes, Flicks, Kid's Stuff, London's Burning, More-On, Napalm, The New Wave, Shews, Sound of the Westway, Strangled, Summer Salt, Sunday Mirra, Surrey's Burning, Tacky/No Future, These Things, Up \& Coming and Zip Vinyl. White Stuff was produced by Sandy Robertson, who moved from Scotland to London in the period between writing and printing the first edition of his fanzine. Tony Drayton also moved to London in 1977, bringing his Ripped \& Torn 'zine with him. He later launched the influential Kill Your Pet Puppy on 1 January 1980, at an Adam and the Ants gig. Zip Vinyl was written in French by Mark Loge and P. Sarfatee, both based in London.

${ }^{10}$ For example: Damaged Goods (York), Look at the Time (Peterborough), Love and Peace and Negative Reaction (Cambridge), Punkture (Stone), Breakdown and Reaction (Southampton), Revenge (Grimsby), Rotten to the Core (Nottingham), Situation Vacant (Derby), Spit in the Sky and Stranded (Exeter), Strange Stories (Southend), Viva La Resistance (Preston) and Vomit (Norwich).

${ }^{11}$ In London, Compendium Books, Rock On, Rough Trade and Small Wonder sold 'zines (Rat Scabies of The Damned called Rock On the 'W.H. Smith of punk rock', Gun Rubber, 5, 1977, p. 20.); elsewhere independent book and record shops did likewise, as did Virgin. Gigs, however, were the main site of sales - raising money for drinks in the process - before fanzine reviews in the 'zines enabled postal networks to develop. Some 'zines were given away free, but most sold at a low cost of between $5 p$ and $50 p$.
} 
Burning (1976), by the journalist Jonh Ingham [sic], comprised collages of newspaper straplines, photos and Clash lyrics, while the first edition of Jon Savage's London's Outrage (1976) interspersed media clippings with pop cultural references and an essay forewarning Britain's descent into fascism. The second issue, produced in 1977, compiled photographs of desolate and graffitied London landscapes that reflected punk's dystopian vision of 'No Future' (see figure 2). ${ }^{12}$ Indeed, the graphic design of punk 'zines soon advanced to incorporate collage, montage, illustration and a wider colour palette that contrasted with the simply-typed or handwritten black-and-white aesthetic of most earlier examples. The influence of Crass, who sought to turn punk's rhetorical reference to anarchy into coherent practice, led to a groundswell of overtly political 'zines. The best of these - Acts of Defiance, Anathema, Enigma, Fack, New Crimes, Pigs for Slaughter, Toxic Graffitti [sic] ${ }^{13}$ - mixed limited music coverage with political tracts on subjects such as vivisection, nuclear war, squatting and the various organizational and intellectual props of 'the system'. Others, such as Vague, began as fairly conventional fanzines before transforming through in-depth analyses of punk's socio-cultural relevance to expanded essays on situationist practice and the Red Army Faction. ${ }^{14}$ Rapid Eye Movement, too, morphed from a punk 'zine into a booklength compendium exploring what its founder, Simon Dwyer, called 'occulture'. ${ }^{15}$

\footnotetext{
12 London's Burning, No. 1, 1976; London's Outrage, Nos. 1 \& 2, 1976-77.

${ }^{13}$ The spelling of 'graffiti' changed with each issue - e.g. Graffitti, Grafitty, Grafity and Graffity.

${ }^{14}$ For extracts, see The Great British Mistake: Vague, 1977-92, Edinburgh: AK Press, 1994.

${ }^{15}$ See Rapid Eye, Vols. 1-2, London: Annihilation Press, 1989-92. A third volume was published by Creation Books in 1995.
} 


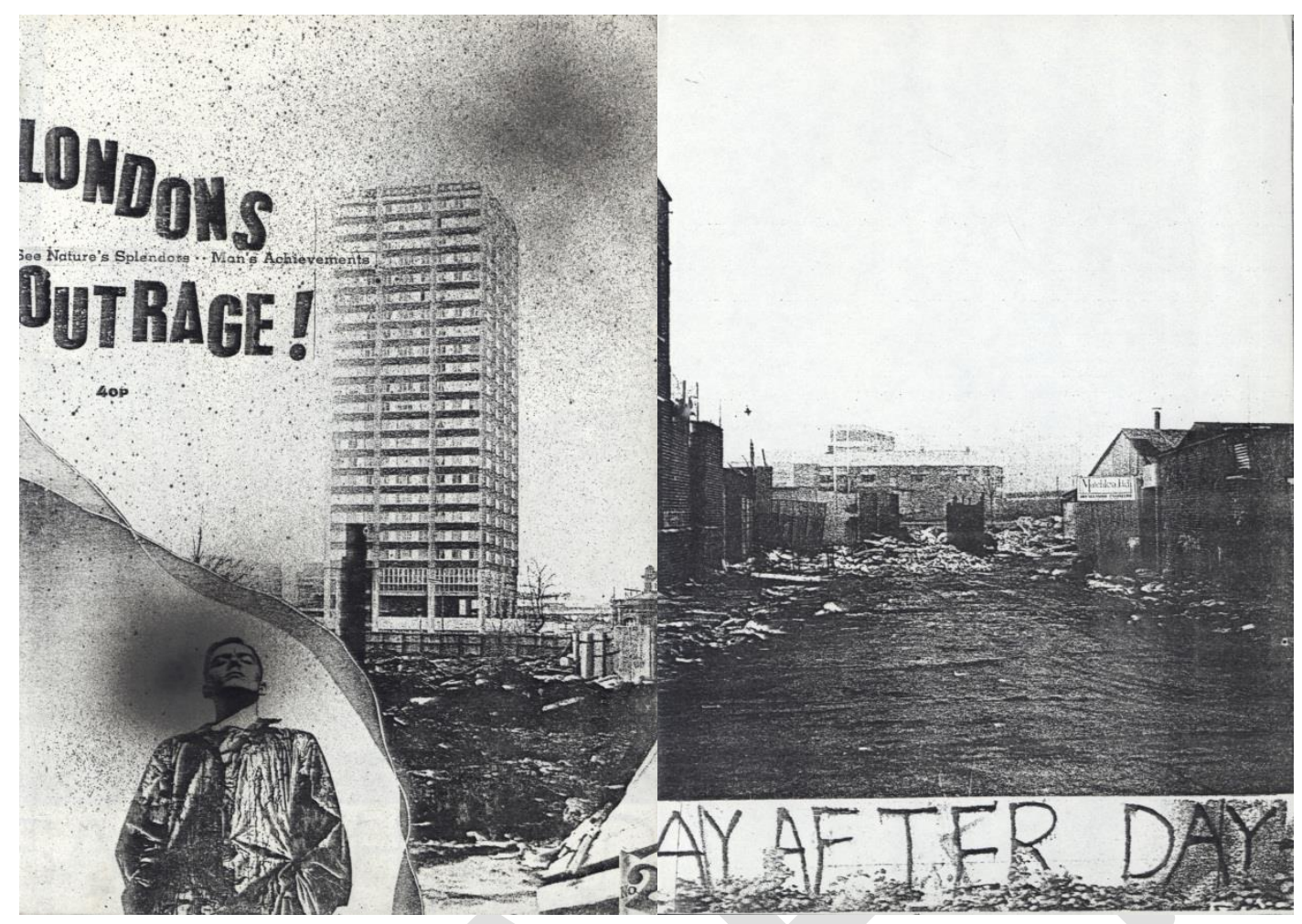

As this suggests, the fanzines that emerged with punk soon transcended their 'fan' prefix. ${ }^{16}$ Some were produced by collectives to augment social networks; others allowed for political (including anarchist, fascist, feminist and socialist) agendas to be applied through punk and the so-called 'post-punk' cultures that formed in its wake. By so doing, they forged a subterranean web of alternative media through which dissenting voices and formative political opinions could be expressed and discussed. The objective of this article, therefore, is to recover and contextualize the political content of fanzines associated with British punk into the 1980s. It will examine the emergence of cultural critiques informed by punk's relationship to popular music and the culture industry; the expression of broadly socialist ideas stimulated by punk and the 'cultural turn' on-going across the left; and the formulation of a recognisably anarchist politics born of punk's DIY ethos. More generally, the article sheds light on a culture described by Jon Savage as akin to the English tradition of

\footnotetext{
${ }^{16}$ For explicit rejection of the 'fan' prefix, see Antigen, No. 1, 1982, p. 2; City Fun, Vol. 2, No. 2, 1980, p. 2; Toxic Grafitty, No. 4, 1979, p. 23.
} 
pamphleteering filtered through the counter-cultural politics of the 'psychedelic left and pro-situ' underground press of the 1960s. ${ }^{17}$

\section{'Why read this when you can produce your own!!!'18}

The history of fanzines has been well told. ${ }^{19}$ Their origin can be traced back to the homemade magazines produced by science fiction fans in the US and Britain from the 1930s; labours of love that enabled stories and critical commentaries to be shared among enthusiasts. Thereafter, non-commercial and non-professional publications emerged across a range of cultural spheres, from comics, sport and cinema to sexuality and religion. Not surprisingly, music provided - and continues to provide - a particularly fruitful site of fanzine activity, with publications concentrated on specific genres or artists dating back to at least the 1950s. To this extent, many of the early punk fanzines followed in a set tradition, providing celebratory coverage of the 'new wave' for the appreciation of like-minded 'fans'.

And yet, the sheer number of punk-informed fanzines that appeared from 1976-77 suggests they signalled more than a simple by-product of musical consumption. Already, by the 1960s, the distinction between fanzines, counter-cultural publications (such as Frendz, International Times, $\mathrm{Oz}$ ) and samizdat-style pamphlets rooted in a longer radical tradition had become blurred. ${ }^{20}$ Indeed, these three points of connection were conjoined via Jamie Reid, whose artwork for the Sex Pistols used détourned media graphics and concepts

\footnotetext{
${ }^{17}$ Savage, England's Dreaming, p. 279.

${ }^{18}$ The title of this section is taken from Cool Notes, No. 3, 1982.

19 Teal Triggs, Fanzines, London: Thames \& Hudson, 2010, p. 18; Stephen Duncombe, Notes from the Underground: Zines and the Politics of Alternative Culture, Bloomington: Microcosm Publishing, 2008 edition, pp. 15-17; Roger Sabin \& Teal Triggs (eds), Below Critical Radar: Fanzines and Alternative Comics from 1976 to Now, Hove: Slab-O-Concrete, 2000; Chris Atton, Alternative Media, London: Sage, 2002; Fredric Wertham, The World of Fanzines, Illinois: Southern Illinois Press, 1973.

${ }^{20}$ Nigel Fountain, Underground - London's Alternative Press, 1966-74, London: Comedia, 1988; Jeff Nuttall, Bomb Culture, London: Paladin, 1970 (originally published 1968); Peter Stansill and David Zane Mairowitz (eds), BAMN: Outlaw Manifestos and Ephemera, 1965-70, London: Penguin, 1971.
} 
cultivated during his time at Croydon Art School (with Malcolm McLaren and Helen Wallington-Lloyd) and disseminated through the Suburban Press he co-founded in 1970. The Sex Pistols' own fanzine, Anarchy in the UK (1976), displayed such a pedigree, featuring pictures of the band's early coterie with politically-charged skits that subscribed to one criterion: 'Does it threaten the status quo?' ${ }^{21}$ Crass, too, issued the first of three International Anthem 'zines in late 1977, juxtaposing Gee Vaucher's artwork with collages, lyrics and extended essays by Penny Rimbaud [Jeremy Ratter] that revealed the band's counter-cultural heritage (see figure 3). As a result, punk and its associated fanzines came imbued with a subversive aesthetic that helped tender broader political potential. As bands wrote songs with political content and aligned themselves to causes such as Rock Against Racism (RAR) and the Campaign for Nuclear Disarmament (CND), so fanzines provided the space to debate and determine the wider implications of punk's cultural politics.

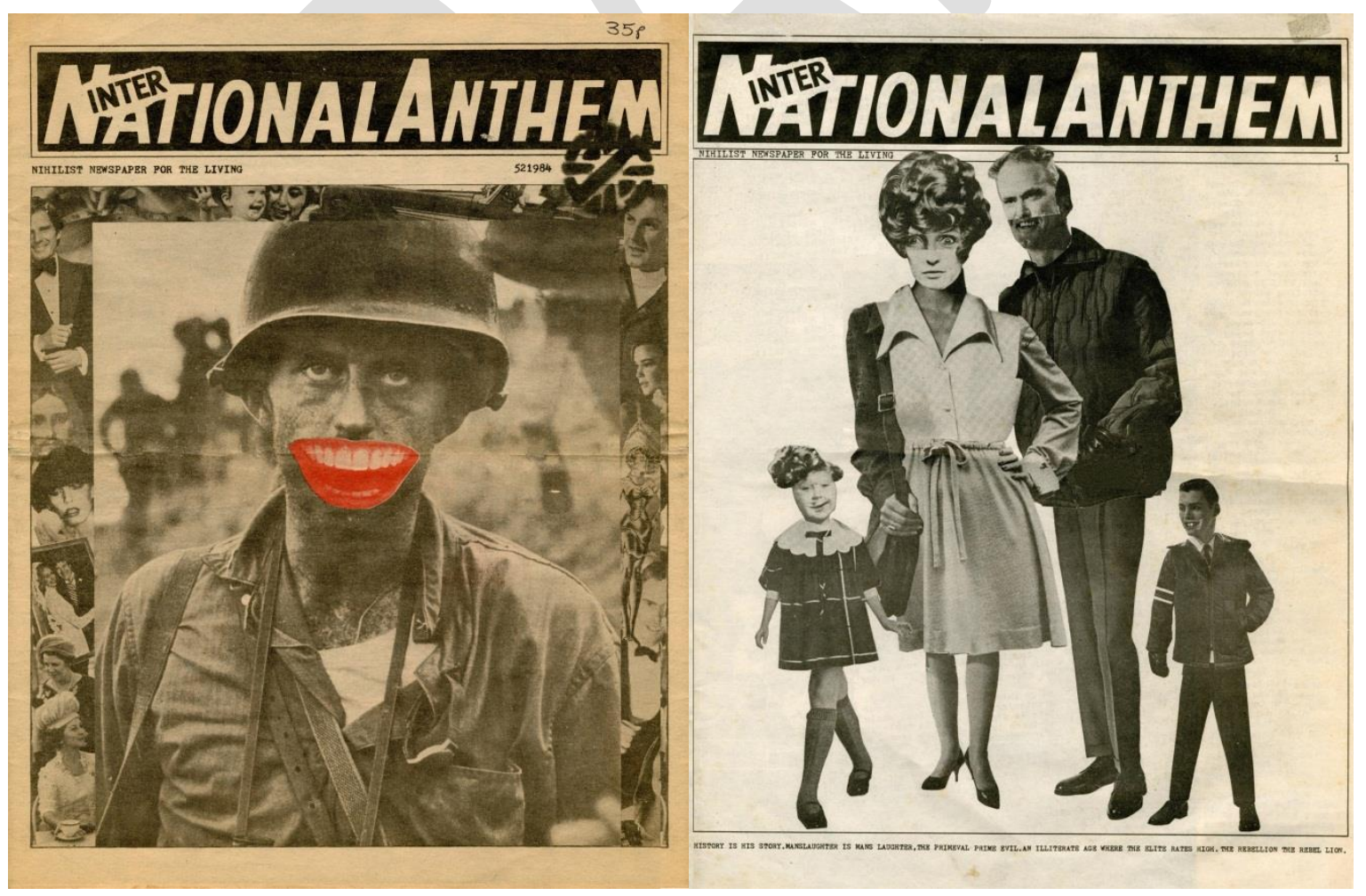

${ }^{21}$ Anarchy in the UK, No. 1, 1976. 
This was recognized at the time. For Tony Parsons, having been recruited to the $N M E$ with Julie Burchill in late 1976 to cover punk's emergence, fanzines represented 'the largest, nastiest, funniest and healthiest selection of alternative music press in the history of rock ' $n$ ' roll' ${ }^{22}$ That is, fanzines offered a creative space to contest and circumvent what Cobalt Hate described in 1980 as the 'bullshit ridden' coverage of the weeklies. ${ }^{23}$ Not dissimilarly, Jon Savage noted in 1976 how fanzines provided a literary and graphic complement to punk's musical and stylistic assault. As well as democratizing youth cultural practice, fanzines pioneered a 'new language' in the form of 'visual and verbal rants' freed from the pressures of censorship, editorial dictates, subbing or deadlines. ${ }^{24}$

Most scholarly analyses of British punk fanzines have picked up on similar themes. Teal Triggs, in particular, has done much to extol the graphic innovations of punk 'zines, demonstrating how their visual language formed an essential part of punk's cultural revolt and helped forge a unique aesthetic that has since been absorbed into conventional design. Both Triggs and Tricia Henry have made explicit the extent to which punk's graphics resembled (and occasionally drew from) approaches pioneered by modernist art forms earlier in the century. ${ }^{25}$ More broadly, sociological accounts of British punk have - like Savage before them - noted how a fanzine's cut ' $n$ ' paste assemblage reflected the culture's early sartorial bricolage and sense of agency. Dick Hebdige, for example, pointed to the

\footnotetext{
${ }^{22}$ Tony Parsons, 'Glue Scribe Speaks Out', NME, 12 February 1977, p. 12. Parsons' early support for fanzines was short-lived, see Julie Burchill and Tony Parsons, The Boy Looked at Johnny: The Obituary of Rock ' $n$ ' Roll, London: Faber \& Faber, 1987 edition, pp. 36-7 (originally London: Pluto Press, 1978).

${ }^{23}$ Cobalt Hate, No. 3, 1980, p. 2.

${ }^{24}$ Savage, 'Diary entry', 8 December 1976, in England's Dreaming, pp. 279-80.

${ }^{25}$ Triggs, Fanzines, pp. 16-17; idem, 'Alphabet Soup: Reading British Fanzines', Visible Language, 29: 1, 1995, pp. 72-87; idem, 'Scissors and Glue: Punk Fanzines and the Creation of a DIY Aesthetic', Journal of Design History, 19: 1, 2006, pp. 69-83. See also Tricia Henry, 'Punk and Avant Garde Art', Journal of Popular Culture, 17: 4, 1984, pp. 30-6; Russ Bestley and Alex Ogg, The Art of Punk, London: Omnibus Press, 2012; Johan Kugelberg and Jon Savage (eds), Punk: An Aesthetic, New York: Rizzoli, 2012; Jon Savage, Punk 45: Original Punk Rock Singles Cover Art, London: Soul Jazz, 2013. For contemporary recognition of this, see Jonh Ingham's dedication to John Heartfield in London's Burning, No. 1, 1976, p. 2; Wendy Shock, 'Dadadadadada ...', Negative Reaction, No. 5, 1978, p. 13; The Eklektik, No. 2, 1982.
} 
jumbled pagination, spelling mistakes and cheap production values of punk fanzines as an indication of their 'urgency and immediacy [...] memos from the front line'. ${ }^{26}$ Dave Laing, meanwhile, emphasized how the language and imagery used by fanzines helped define punk's boundaries within (and against) the music industry and society more generally. ${ }^{27}$ If the abiding legacy of punk was to provide a cultural process that transformed the passive observer into active participant, then fanzines deserve their place alongside the independent labels and self-released records that so readily embodied the DIY spirit. ${ }^{28}$

Such approaches make sense. The cut-up imagery and irreverent text of most fanzines did indeed replicate punk's acerbic style which, in turn, appeared to embody the rhetoric of social dislocation and decline that shaped the media and political discourse of the 1970s. Simultaneously, the very process of writing and distributing a fanzine affirmed punk's stated intention of reclaiming popular music and youth culture for those who made, listened to and lived it. Guides to producing a fanzine became a staple feature of punk 'zines, as important as Sideburns' seminal diagram of three chords and the instruction: 'This is a chord. This is another. Here's a third. Now form a band' (see figure 4). ${ }^{29}$ Furthermore, the content of most British fanzines revealed punk to be very much a conscious response to on-going cultural and political developments.

\footnotetext{
26 Dick Hebdige, Subcultures: The Meaning of Style, London: Routledge, 2007 edition (originally published 1979), pp. 111-12. See also Shane MacGowan's sign-off in Bondage, No. 1, 1976, p. 6: 'This whole things was put together etc. etc. with the help of a box of safety pins. All the photos are ripped out of other mags. Sorry it's all hand-written but I haven't got a typewriter'.

${ }^{27}$ Dave Laing, Once Chord Wonders: Power and Meaning in Punk Rock, Milton Keynes: Open University Press, 1985, pp. 14-15.

${ }^{28}$ Alex Ogg, Independent Days: The Story of UK Independent Record Labels, London: Cherry Red, 2009; Rob Young, Rough Trade, London: Black Dog, 2006; David Hesmondhalgh, 'Post-Punk's Attempt to Democratise the Music Industry: The Success and Failure of Rough Trade', Popular Music, 16:3, 1998, pp. 25-74.

${ }^{29}$ Sideburns, No. 1, 1977, p. 2. For guides to making a fanzine, see Adventures in Reality, Issue G, 1981, p. 21; Alternative Sounds, No. 17, 1980, p. 15; City Fun, No. 3, 1978, p. 4; Guttersnipe, Vol. 2, No. 1, 1980, p. 7; Rising Free, No. 6, 1983, pp. 14-15.
} 


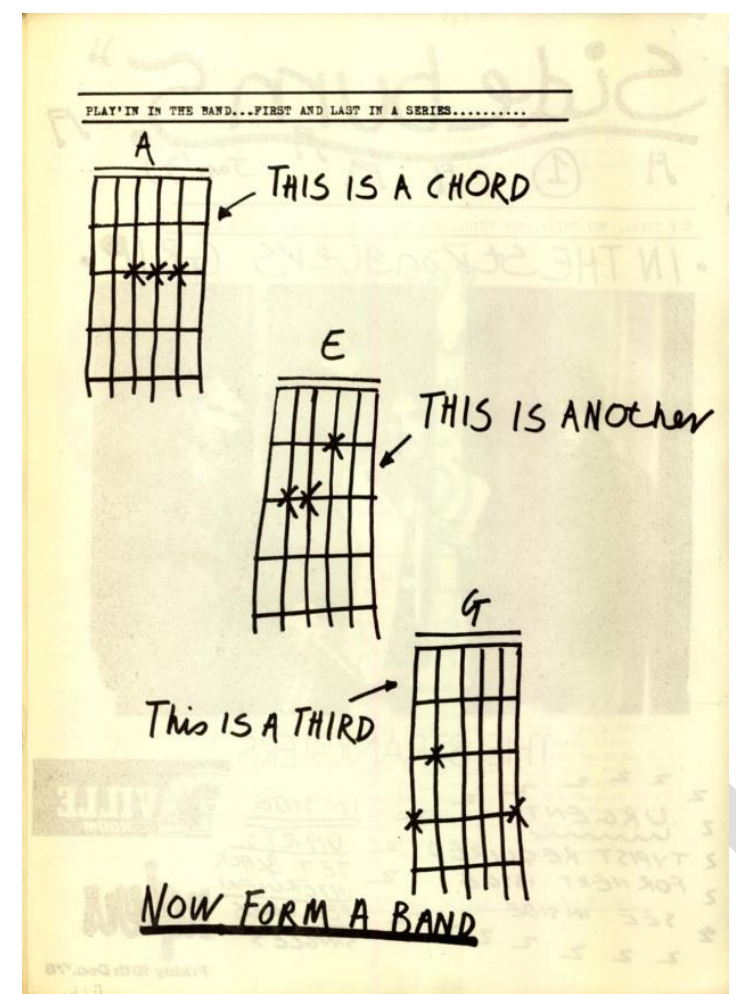

We should not overstate matters. There were countless fanzines that simply imitated the existing music press, providing less an alternative than a weak complement. Many, too, remained fixated on music and the internal dynamics of youth culture, squabbling as to just who or what constituted 'punk' and delineating those tribal rivalries (punks, teds, mods, skins etc.) that too often spilled over into violent confrontation. ${ }^{30}$ Record reviews, self-made charts, band interviews and tales of a night out watching a gig continued to provide the bulk of a typical fanzine's copy. In other words, they comprised the usual concerns of teenagers enthused by pop music and the shifting contours of style and taste within popular culture more generally.

Nevertheless, punk also generated overtly political expression. Though its obituary was drafted many times within the music press and media, punk's enduring relevance and diffusion continued long into the 1980 s and was chartered across a seemingly never-ending

\footnotetext{
${ }^{30}$ See, for an entertaining example, the interview with a teddy boy in Fair Dukes, No. 2, 1977, pp. 9-11.
} 
production line of fanzines. ${ }^{31}$ Some of these, moreover, set out to define and direct punk's purpose beyond the 'enjoyment' demanded in the first issue of Sniffin' Glue and towards more ambitious objectives of cultural and political change.

\section{'Freedom is precious, most people don't have it, they suffer quietly away from our TV} screens $^{\prime 32}$

Punk, initially at least, was presented as a response to the perceived state of popular music in the mid-1970s; that is, to a diluted pop mainstream (as broadcast on Top of the Pops and Radio One) and the domination of rock ' $n$ ' roll by an increasingly aged and detached elite. ${ }^{33}$ Just as The Clash dismissed 'Elvis, Beatles [and] the Rolling Stones' as irrelevant to the lives of young people in 1976-77, so Tony D [Tony Drayton] opened his first issue of Ripped \& Torn with a tirade against 'those boring cunts (like the whole of Led Zeppelin, The Who, Paul McCartney, Stevie Wonder etc.) lazing away in some hot tropical paradise, whilst us poor punters have to make do with any shit they care to pour on us. ${ }^{34}$ At the very least, punk signalled a generational, stylistic and attitudinal shift in popular music and its associated culture.

Such interpretation formed the basis of much early fanzine content. 'Zines helped reaffirm the idea of punk as a challenge to the mainstream music and media industries,

\footnotetext{
31 Just a few notable examples would include: 0533 (Leicester), Alternative Sounds (Coventry), Artificial Life (London), Attack on Bzag (Leeds), Burnt Offering (Northampton), City Fun (Manchester), Dayglow (London), Final Curtain (Grays), Grim Humour (Herne Bay), Grinding Halt (Reading), Guttersnipe (Telford), Hard as Nails (Canvey Island), Have a Good Laugh (Newcastle), Harsh Reality (Ipswich), Hit Ranking (Cheam), Inside Out (Edinburgh), Kick (London), Kill Your Pet Puppy (London), New Crimes (Southend), NMX (Sheffield), Raising Hell (Leeds), Ready to Ruck (Folkestone), Safety in Numbers (Portsmouth), Suss (Luton), Trees and Flowers (King's Lynn) and Vague (Salisbury/London).

${ }^{32}$ Taken from Bits, No. 1, 1981.

${ }^{33}$ See, for example, Paul Simonon (The Clash) in Negative Reaction, No. 5, 1977, p. 5, commenting on the origins of punk: 'It's kids who watch Top of the Pops, and they see all these shitty groups, and there's nothing to do. And they see a guy play guitar in a club and they think it takes about a hundred years to learn to play.'

${ }^{34}$ Tony D, 'Can Rich “Stars” Rock?', Ripped \& Torn, 1, 1976, pp. 5-6.
} 
demystifying their processes and opening-up access to production and dissemination. Or, to quote Rick O'Shea in Heat (1977), punk meant 'putting yourself against established systems [...] makin' a stand and clearing the way for other bands to follow'. The aim, as Mark Perry saw it, was to 'take in everything, including posters, record covers, stage presentation, the lot! ${ }^{35}$ Fanzines, by extension, were designed to facilitate this by providing a medium through which those closest to the culture could define, contest and shape it from within. 'It is up to us, the audience', Edinburgh's Hangin' Around (1977) insisted, 'to cast out the bandwagon jumpers and free loaders and to weed out the posers and the money grabbers'. $^{36}$

What this meant in practice could vary. As well as giving the institutionalized music industry' a 'good $\mathrm{kick}^{\prime 37}$, fanzines tended to elevate local or grass-roots expressions of punk culture above those presented by the national music papers or record industry. While Sheffield's Gun Rubber featured a graffitied wall displaying the slogan ‘I don't care about London', later 'zines - e.g. Anti-Social (Coventry), Defused (Cumbria), Wool City Rocker (Bradford) - actively prioritized coverage of local artists as editorial policy. 'Name' bands were interviewed and reviewed as they passed through a particular town or city, but most fanzines found space to promote local groups, clubs and records. Some even became closely related to local venues, such as Bradford's Knee Deep in Shit, which covered the city's '1 in 12 club' from 1981, while others set up cassette labels to distribute compilations and demo tapes through the fanzine network. ${ }^{38}$

\footnotetext{
${ }^{35}$ Rick O’Shea, 'Punk Rock Rules', Heat, No. 2, 1977, p. 13; Mark P, “Ope I Die Before I Get Old', Sniffin Glue, No. $3 \frac{1}{2}, 1976$, p. 4.

36 'So What Else in New?', Hangin' Around, No. 6, 1977, pp. 3-4.

${ }^{37}$ Tim T., 'Punk is ...', Blades ' $n$ ' Shades, No. 1, 1977, p. 2

${ }^{38}$ See also Barbequed Iguana, a fanzine linked to The Jacquard club set by Jon Fry and Jon Vince in Norwich. For cassettes, see 'zines such as Apathy (Bradford), Hit Ranking (Cheam), New Crimes (Southend) and New Systems (Penarth). For examples of the cassette network, Stabmental, No. 2, 1980, pp. 9-11, New Crimes, No.
} 
Not dissimilarly, 'zines served as a point of connection between bands and the wider punk culture. Those interviewed were typically quizzed as to their politics, their objectives and the amount of money they earned or conditions of their contract. For bands to appear disconnected from their audience base was to provoke accusations of succumbing to the lure of the star-system and betraying their punk roots. Most notoriously, perhaps, The Clash soon came under attack for their apparent absorption into the rock ' $n$ ' roll mainstream, though other bands were similarly mocked, condemned or ignored once they were deemed to have transgressed punk's shifting parameters in one way or another. ${ }^{39}$

Finally, 'zines offered a very real alternative to the established music press, covering bands and scenes dismissed by the NME et al., and enabling those within the culture to rebut media distortions and reassert cultural identities. The cult-status of the pre-pop Adam \& the Ants can only really be understood through the attention given by Panache, Vague and specialist 'Ants-zines' produced at the turn of the decade. ${ }^{40}$ Nor can the brief-butnotable influence of bands such as A.P.F. Brigade, Brigandage, Crisis, Six Minute War or UK Decay be adequately appreciated without reference to fanzines. Crass, meanwhile, tended to eschew contact with a music press they considered little more than a conduit for corporate interests, preferring instead to give interviews to fanzines through which they also distributed statements and information. ${ }^{41}$ Coming from a different direction, 'zines such as Hard as Nails and Skinhead Havoc did much to reassert street-level cultures in the face of challenges from the far-right and distortions within the mass media. In particular,

6, 1982, p. 20 and New Systems, No. 1, 1982, pp. 2-3. A few 'zines also issued flexi-discs or singles (e.g. Grinding Halt, In the City, Sniffin' Glue, Toxic Grafity and Trees and Flowers).

${ }^{39}$ Anti-Climax, from Ipswich, seemed to revel in its dismissal of The Clash, but see also 'All the Glitters Turns to Rust', Anathema, No. 2, p. 21; 'Money Corrupts', Chainsaw, No. 5, 1978, p. 7; Youth in Asia's 'CBS (Cash Before Sincerity)', Hit Ranking, No. 16, 1982, p. 18

${ }^{40}$ These included Family of Noise, Ligotage, The Night Porter and Zerox.

${ }^{41}$ See, for example, Bring into Being, No. 1, 1983; Fight Back, No. 1, 1984; Intensive Care, No. 2, 1980; Kill Your Pet Puppy, No. 1, 1980; Toxic Grafitty, No. 4, 1979. 
they covered reggae and soul to reveal a far broader cultural heritage than that depicted in the music weeklies or tabloids. ${ }^{42}$

At a basic level, then, fanzines allowed those engaged with punk to construct their own cultural narratives. These, in turn, fed into a hardening critique of the media and music industry that shaped punk's cultural politics. First, the machinations of the music business were dissected and related to broader analyses of cultural commodification. For David George, writing in Dirt (1978), punk's exploitation by an 'arrogant capitalism' reaffirmed the need for bands and 'zines to critically assess their commitment to a 'non-sexist, non-racist, non-violent, non-capitalistic, non-exploitative rock movement ${ }^{43}$ As this implies, fanzines tended to emphasize their non-profit motive, with prices set low to cover costs and content designed without consideration of commercial impact. ${ }^{44}$ Preference was similarly given to bands that sought to by-pass major labels in favour of smaller independents or self-released their own records. Tony Medlycott, whose Aftermath surveyed punk's dissemination across east London in 1979-81, saw independently-produced records (and 'zines) as the basis for a 'new underground'; an 'opposition' concerned with 'putting over their views' rather than pandering to 'record companies, popular radio, large audiences and so on' ${ }^{45}$ Indeed, such affinities were confirmed by Rough Trade's willingness to distribute 'zines though its emergent distribution network and by the nearby Better Badges' offer to print fanzines on a

\footnotetext{
${ }^{42}$ Other examples include Ready to Ruck, Skins and Tell Us the Truth. See also 'zines such as Boots \& Braces, Cool Notes and Stand Up and Spit, which covered soul and reggae beyond mere token reference. Indeed, reggae fanzines such as Nick Kimberley and Penny Reel's Pressure Drop (1975) and, later, Ital Rockers and Small Axe, could form the basis of an equally useful analysis of fanzine culture. In the mainstream, Black Echoes helped fill a void in music coverage of the period.

${ }^{43}$ David George, 'The End', Dirt, No. 1, 1978, p. 3.

${ }^{44}$ The fact that some fanzines included adverts proved contentious, while price-rates provoked questions of moral economy. Indeed, certain titles, such as In the City and Jamming, were criticized by other 'zines (and their readers) for being too commercially orientated.

45 'The Opposition (The New Underground)', Aftermath, No. 3, 1980, p. 13.
} 
'print now, pay later' basis. ${ }^{46}$ The result, of course, was to expand the potential reach of a fanzine and prompt an increase in the number of titles available.

Second, a fanzine's media critique often extended beyond the perceived limitations of the music press. The power of the media proved a constant source of fascination in punk and was reflected in countless band names, song titles/subject-matter and graphics. ${ }^{47}$ In particular, punk revealed and explored how the media commodified, objectified and anaesthetized. So, for example, The Secret Public, published by Linder [Linda Mulvey] and Jon Savage in 1978, comprised photomontages that spliced together pornographic images, household appliances and advert-speak to expose the gendered false promises of the media spectacle. More generically, at least by the 1980s, 'zines used newspaper lettering and cutout headlines to reassert punk's contemporaneity and sense of engagement. Headlines depicting crisis or horror were juxtaposed with bland advertising imagery, while benign media set-pieces (a woman in a kitchen, children playing) were set against acerbic essays on gender stereotyping or impending war (see figure 5). In effect, television, radio and the print media were recognized as forces of control that reinforced social moralities, stifled dissent and distracted from the inequities of everyday life. ${ }^{48}$

\footnotetext{
${ }^{46}$ Tony Fletcher, 'Better Badges and Fanzines', Jamming, No.1980, pp. 13-16. See Tony Fletcher, Boy About Town: A Memoir, London: William Heinemann, 2013.

${ }^{47}$ A few obvious examples amongst hundreds: The Adverts, Alternative TV and Magazine; the covers of The PiL's 'Public Image' and The Exploited's 'Dead Cities' singles, Sham 69's That's Life album cover; Cock Sparrer's 'The Sun Says' and The Jam's 'News of the World'; the lyrics to Subway Sect's 'Nobody's Scared' ('Media teach me what to speak/take my decisions').

${ }^{48}$ See, for example, 'The Spectacle', A System Partly Revealed, No. 2, 1982, p. 5; 'Fuck the Press', Live Wire, No. 7, 1977, p. 4; 'Wake Up World', Ripped \& Torn, No. 16, 1979, p. 13; 'Don't Believe Media Lies', Sunday the $7^{\text {th }}$, No. 2, 1981, pp. 12-13. A System Partly Revealed was produced by John Cato, who bookended his anarchism with stints in the British Movement and Combat 18, both Neo-Nazi organisations.
} 

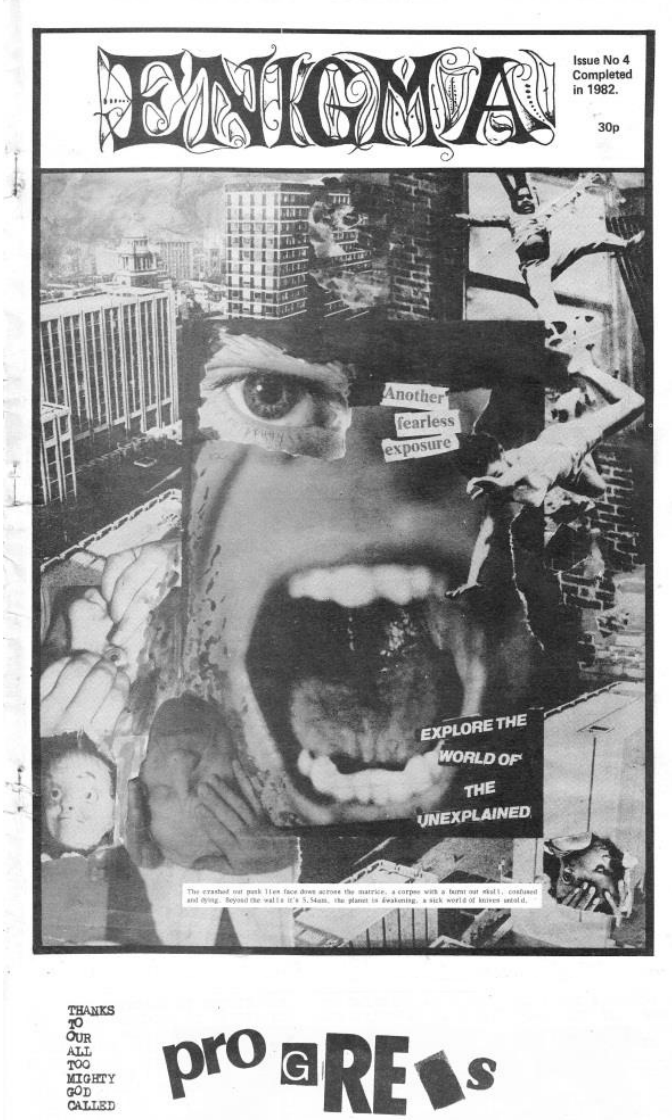

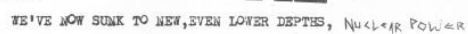

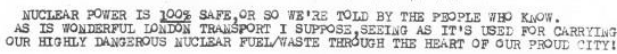

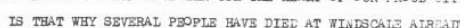

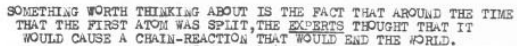

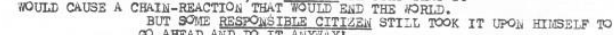

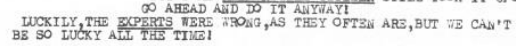

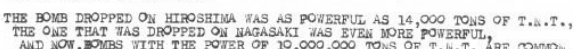

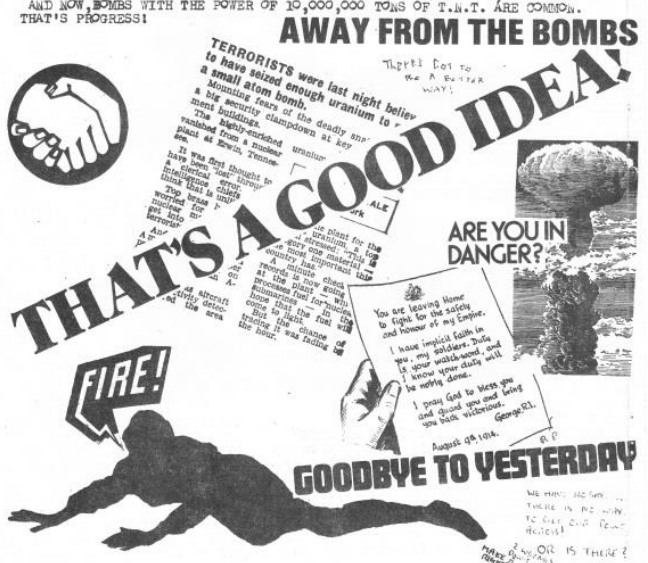

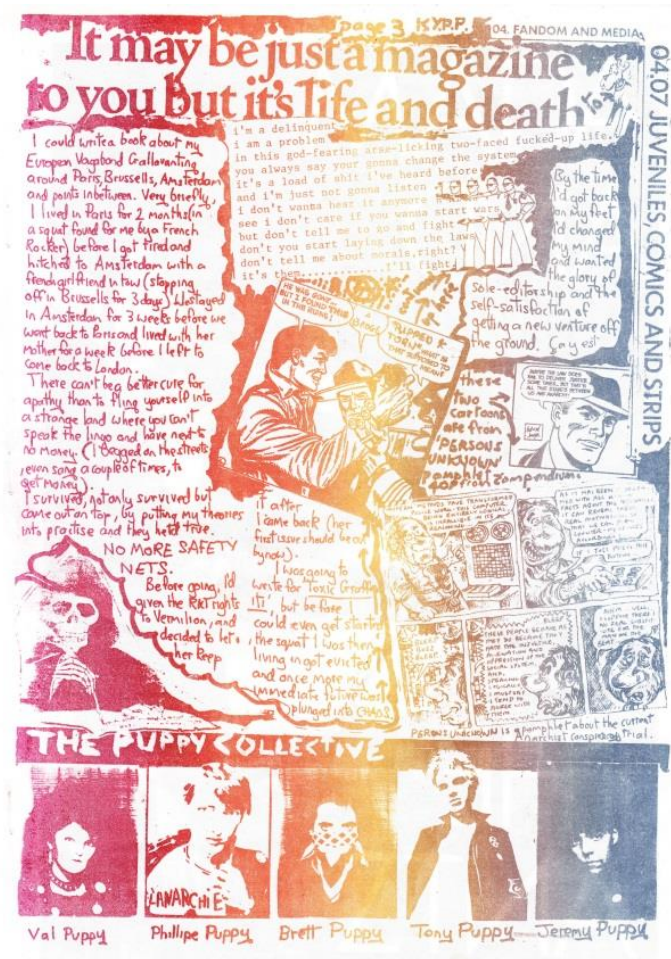

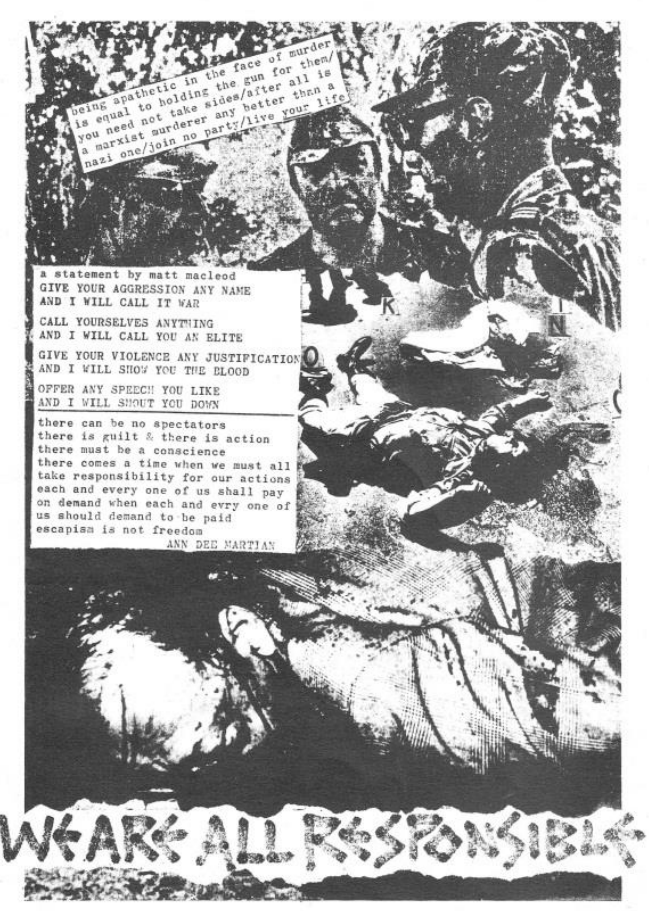

Such critical analyses were partly born of experience. Punk had entered the wider public consciousness on the back of a media-generated moral panic following the Sex Pistols' infamous appearance on Thames Television's Today programme on 1 December 1976. It had also been codified and commodified over the course of 1977 , revealing the 
speed by which its perceived challenge could be disarmed, repackaged and transferred into profit. Certainly, by late 1977, a note of despondency was discernible in fanzines as they assessed punk's impact and future potential. Rants against 'posers' and the commercial availability of a punk 'uniform' became standard copy long into the $1980 \mathrm{~s}^{49}$

Equally, however, punk's appraisal of the media and the exploitative nature of the music industry bore traces of critical analyses that had gained prominence over the $1960 \mathrm{~s} .{ }^{50}$ This, in part, was due to the influence of those such as Malcolm McLaren, Jamie Reid, Bernie Rhodes and Penny Rimbaud whose familiarity with counter-cultural or leftist politics fed into punk's construction. ${ }^{51}$ But it also revealed punk's interrelationship with broader debates as to the political significance of cultural form and practice. Almost from the outset, punk had been defined either as a product or a reflection of the severe economic and political dislocations of the 1970s. It should be no surprise, therefore, that punk's fanzines referenced and engaged with the political environment into which they emerged.

\section{Rock ' $n$ ' roll magazines for the modern world ${ }^{52}$}

British punk emerged and developed at a distinct historical juncture. Although scholars have begun to question both the nature and extent of the 'crisis' facing Britain in the 1970s (demonstrating how its meaning was constructed and exploited to forge a hegemonic narrative), significant socio-economic, political and cultural change undoubtedly did take

\footnotetext{
${ }^{49}$ Collage, Anti-Climax, No. 6, 1980, p. 8; Pete Nasty, 'Punk Hits the Glossies', Heat, No. 2, 1977, p. 3; Hate and War, No. 2, 1982, p. 6; 'Fashion Parade', IQ32, No. 2, 1983, p. 6.

50 'Popular' expressions of this could include Marshall McLuhan and Quentin Fiore, The Medium is the Massage, London: Penguin, 1967; John Berger, Ways of Seeing, London: Penguin, 1972 (which was also a BBC series). By the 1980s, Guy Debord's Society of the Spectacle (1967) had been translated beyond small anarchist or leftist circles. Debord's influence can be seen via Reid's designing Christopher Gray (Ed.), Leaving the $20^{\text {th }}$ Century: The Incomplete Works of the Situationist International, London: Free Fall, 1974.

${ }^{51}$ For the 'art school' influence on punk and pop music generally, see Simon Frith and Howard Horne, Art Into Pop, London: Methuen, 1987.

${ }^{52}$ Sub-heading adapted from the strapline of White Stuff, No. 1, 1977: 'A rock ' $n$ ' roll magazine for the modern world'.
} 
place. $^{53}$ Indeed, to summarize the defining motifs of the period is to create a textual montage akin to the collages of media straplines and images generated by punk fanzines at the time. Thus we may point to inflationary pressures producing industrial confrontation, economic instability and a 'winter of discontent' (1978-9); to a global economic depression, an oil crisis (1973-4) and a sense of post-imperial insecurity played out via Britain's relations with Europe, devolution debates and the Falklands War (1982); to simmering social tensions evoked by a resurgent National Front (NF), the riotous summer of 1981 and such media 'folk devils' as muggers, football hooligans, glue sniffers and punk rockers; to the bloody conflict in Northern Ireland, mainland IRA bombings and terrorist attacks at home and abroad; to a re-emergent cold war and a revitalized CND; to long-term unemployment, deindustrialization and the picket-line battles that culminated in the miners' strike of 19845. Underpinning it all, moreover, were slower shifts across Britain's socio-economic base from industrial production to the service sector - and evolving socio-cultural attitudes. More generally, the period saw the broadly collectivist values of the post-war settlement give way to the individualist principles of neo-liberalism, as all three British mainstream parties underwent notable realignments and the 'popular authoritarianism' that Stuart Hall recognized as the kernel of Thatcherism buried itself deep into the national psyche. ${ }^{54}$

Punk resonated, at least in part, because it reflected and engaged with the implications of all this. Political symbols, slogans and signifiers of 'crisis' formed a core component of punk's iconography. The early designs of Malcolm McLaren and Vivienne

\footnotetext{
${ }^{53}$ Lawrence Black, Hugh Pemberton and Pat Thane (eds), Reassessing the Seventies, Manchester: Manchester University Press, 2013; Colin Hay, 'Chronicles of a Death Foretold: The Winter of Discontent and Construction of the Crisis of British Keynesian', Parliamentary Affairs, 63:3, 2010, pp. 446-70; Joe Moran, '"Stand Up and Be Counted": Hughie Green, the 1970s and Popular Memory', History Workshop Journal, 70:1, 2010, pp. 173-98; Nick Tiratsoo, "You've Never Had it so Bad": Britain in the 1970s', in idem (ed), From Blitz to Blair: A New History of the Britain since the 1970s, London: Weidenfield \& Nicolson, 1997, pp. 163-90.

${ }^{54}$ Stuart Hall, 'The Great Moving Right Show', Marxism Today, January 1979, 14-20. For a comprehensive overview of the period, see Brian Harrison, Finding a Role? The United Kingdom, 1970-1990, Oxford: Oxford University Press, 2010.
} 
Westwood comprised swastikas, images of Marx, situationist references and quotes from Buenaventura Durruti. The Sex Pistols' second single ('God Save the Queen') provided a critical riposte to 1977's Silver Jubilee celebrations wrapped in a defaced image of the Queen; their first, 'Anarchy in the UK' (1976), coincided with Denis Healey's application to the International Monetary Fund for a loan to offset Britain's economic instability - the song's title providing both a totem of the country's sense of decline and a cry for selfemancipation. As for The Clash, they delivered songs of barbed social commentary that referenced 1976's Notting Hill riot, unemployment, boredom, hate and war. Given the wider context, punk's ire and claims to relevance were easily construed as a youthful reaction to political failure and a bleak (no) future..$^{55}$

Such interpretation soon filtered through the music press and mainstream media into the fanzines. While many involved with punk resisted and rejected the political connotations applied to it, others embraced its potential for critical and political comment. A fanzine such as Guttersnipe (1978-80), for example, was produced by a mainly teenage collective from Telford who juxtaposed gig reviews and band coverage with social realist images of graffitied walls, 'kids' on the street, newspaper clippings and council housing. Inside, articles on anti-racism, teenage sex, Ireland, apartheid and violence were featured alongside interviews with local unemployed youths, ex-Borstal inmates and survivors of failed suicide attempts. The effect was to locate punk as a vehicle for socio-political reportage; a mode of documentation and stimulus for protest. ${ }^{56}$

\footnotetext{
55 For example, Caroline Coon, 'Rotten to the Core', Melody Maker, 27 November 1976, pp. 34-5; Tony Parsons, 'Go Johnny Go', NME, 2 October 1976, p. 29; Dave Marsh, 'Dole Queue Rock', New Society, 20 January 1977, pp. 112-14.

${ }^{56}$ These examples come from Guttersnipe, Numbers 1, 2, 4, 5, 7, 1978-9 and Volume 2, Number 1, 1980. A BBC 'Open Door' documentary was broadcast about the fanzine in 1980.
} 
As this suggests, the substance and look of Guttersnipe chimed with the times to create a veritable 'structure of feeling' ${ }^{57}$ Moreover, its emphasis on youthful disaffection, political tensions and economic crisis was evident in other fanzines keen to align punk's emergence to wider political and social themes. In particular, anti-racism and anti-fascism featured regularly in the late 1970s, partly as a consequence of the NF's presence on certain inner-city streets, and partly in response to a sense by which Britain was heading towards a crisis that would reap only an authoritarian solution. As newspaper editorials evoked fears of socio-economic collapse and rumours of military (or 'communist') coups circulated, so punk's lyrics and imagery responded to and echoed the media clamour. ${ }^{58}$ Articles critiquing punk's adoption of the swastika appeared in Jolt and Ripped \& Torn, images of NF marches fed into fanzine photomontage, while the fourth issue of Flicks presented itself with a large swastika covered by the slogan 'smash fascism'. ${ }^{59}$ Not dissimilarly, tales of police harassment and terse dismissals of the political establishment reaffirmed the notion of punk as a creative response to despondency, especially as the 1970 s gave way to the 1980 s. $^{60}$

To some extent, the politicized content of punk fanzines was informed by attempts on the left and far right to claim - or use - punk for ideological purposes. ${ }^{61}$ So, for example, members of the Young Communist League (YCL), Socialist Workers Party (SWP) and other leftist tendencies interpreted punk as a retort to capital's failings: a means to 'protest

\footnotetext{
${ }^{57}$ This, of course, refers to Raymond Williams' notion of a 'culture as lived', as developed most completely in his Marxism and Literature, Oxford: Oxford University Press, 1977.

${ }^{58}$ For a discussion of supposed military coups and authoritarian clampdowns, see Roger King and Neill Nugent (eds), Respectable Radicals: Middle-Class Campaigns in Britain in the 1970s, London: Hodder \& Stoughton, 1977; Phillip Whitehead, The Writing on the Wall: Britain in the Seventies, London: Brook, 1985, pp. 202-20. Andy Beckett, When the Lights Go Out: Britain in the Seventies, London: Faber \& Faber, 2009, pp. 376-82.

${ }^{59}$ Bored Stiff, No. 2, 1977, p. 2; Breakdown, No. 1, 1977; Flicks, No. 4, 1977; 'Smash the National Front Now', Gabba Gabba Hey, No. 3, 1977, p. 9; Lucy Toothpaste, 'Off Your Rocker', Jolt, No. 3, 1977, p. 7; 'When Did You Stop Wearing Nazi Paraphernalia?', Ripped \& Torn, 7, 1977, p. 7.

${ }^{60}$ For example, see Bits, No. 1, 1981; Kick, No. 4, 1982, p. 5; Nihilistic Vices, No. 1, 1979; Toxic Graffitti, No. 3, 1979.

${ }^{61}$ Matthew Worley, 'Shot By Both Sides: Punk, Politics and the End of "Consensus"', Contemporary British History, 26/3, 2012, 333-54.
} 
against the frustrations and conditions that affect working-class youth' ${ }^{62}$ Similarly, on the far right, punk was understood by some young activists as a violent and exciting reaction to the 'hum-drum life of the liberal society'. ${ }^{63}$ Not surprisingly, therefore, the fanzines produced from 1976 soon fed into an on-going debate as to the meaning of specific (youth) cultural forms and their potential for facilitating social and political change. In other words, fanzines were recognized either as a form of alternative media to the mainstream or as samizdat-style publications designed to propagate radical perspectives. The YCL displayed its affinity to punk's youthful revolt by revamping the graphic design of its newspaper to reflect that of a fanzine, while the SWP went one better by launching the short-lived Red Rebel, a 'zine-like youth paper that mixed political tracts and interviews with bands such as the Angelic Upstarts. RAR, which worked closely with the SWP and the Anti-Nazi League (ANL) in the late 1970s, also published its own 'zine-style newspaper, Temporary Hoarding, from 1977, combining music coverage with political essays and punk-informed photo-collages of strikes, RAR gigs, slogans and demonstrations. ${ }^{64}$ From the opposite direction, the NF's Eddy Morrison launched a Punk Front fanzine in Leeds in 1978, having already begun to integrate music coverage and racist politics in a smaller, self-produced magazine called British News. Thereafter, both Morrison and Joe Pearce, editor of the Young National Front's Bulldog magazine, initiated Rock Against Communism (RAC) as a counter to RAR, replete with an associated fanzine, Rocking the Reds. ${ }^{65}$

\footnotetext{
${ }^{62}$ Anthony Wall, 'Punk', 5 March 1977, p. 74. See also I. Wright, 'New Wave', Challenge, February-March 1977, p. 14; Dave Laing, 'Interpreting Punk Rock', Marxism Today, April 1978, pp. 123-8.

${ }_{63}$ Interview with Steve Gaunt, a Young National Front organiser in Leeds, British News, March 1978, p. 3.

${ }^{64}$ Fanzine workshops were held at some RAR conferences, with the specific objective of using 'zines to raise political issues and encourage political engagement. See Temporary Hoarding, No. 7, 1978, p. 16; Big Flame, August 1979, p. 11.

${ }^{65}$ Later far-right magazines that may be placed in a 'zine-tradition include White Noise and Blood \& Honour.
} 
Of course, 'zines were also produced independently by young political activists enthused by punk and its potential. The aforementioned Guttersnipe included SWP members among its collective and the early 1980s saw a number of punk-and-poetry 'zines emerge featuring 'ranters' (Attila the Stockbroker, Little Brother, Seething Wells, Mick Turpin, Tim Wells) keen to use the infrastructure of punk to communicate and propagate their socialist politics. A flick through Another Day Another Word (Liverpool), Blaze (Peterborough), Cool Notes (London), Molotov Comics (Leeds), Stand Up and Spit (London) and Tirana Thrash (Harlow) offers a portal into the period of incipient Thatcherism via fierce - if sometimes humourous - tirades against unemployment, fascism, 'trendy lefties', police brutality and the recast shadow of the cold war. ${ }^{66}$

Simultaneously, the political content of punk fanzines related closely to the 'cultural turn' evident in late twentieth-century politics. ${ }^{67}$ As new sites of struggle emerged over the 1950s-60s - in culture, language, youth, race, gender, the media - so the personal became political and greater emphasis was placed on individual responses to questions of sexuality, identity, leisure and pleasure. This, typically, took the form of lengthy interviews with bands such as the Au Pairs, Gang of Four, The Mekons, The Pop Group, The Raincoats, Red Crayola and Scritti Politti on matters of creative autonomy, gender, hegemony and praxis. ${ }^{68}$ But it also expressed itself in poems and short stories that offered stark portrayals of alienation, misogyny and anxiety. ${ }^{69}$ Brass Lip (1979), from Birmingham, focused its attention solely on

\footnotetext{
${ }^{66}$ The listed 'zines were produced by Mick Turpin, Janine Booth, Richard Edwards, Seething Wells (Steven Wells), Tim Wells and Attila the Stockbroker (John Baine). See also various Bradford 'zines from the time that included poems by Joolz, Seething Wells, Nick Toczek and others

${ }^{67}$ Dennis Dworkin, Cultural Marxism in Post War Britain: History, the New Left and the Origins of Cultural Studies, North Carolina: Duke University Press, 1997.

${ }^{68}$ See, for example, Adventures into Basketry (Nottingham), After Hours (London), Dangerous Logic (London), Let's Be Adult About This (London), Mental Children (London), Printed Noises (Manchester) and Voice of Buddha (London).

${ }^{69}$ For example, 'The Working Woman', Acts of Defiance, No. 3, 1982, p. 10; 'Look What is Happening' collage in Between the Lines, No. 1, 1979, p. 7;'Short Story', Black Dwarf, No. 2, 1979, pp. 4-6.
} 
bands committed to exploring gender politics, discussing their relationship to the women's movement and exposing the sexism endemic within the music industry (see figure 6). ${ }^{70}$ Previously, too, Lucy Toothpaste's [Lucy Whitman] Jolt had applied a feminist critique to punk that later found expression through RAR and Rock Against Sexism (RAS). Both Temporary Hoarding and RAS' associated 'zine, Drastic Measures, featured articles by Toothpaste and others on the dynamics of 'Sex \& Violence \& Rock \& Roll' ${ }^{71}$

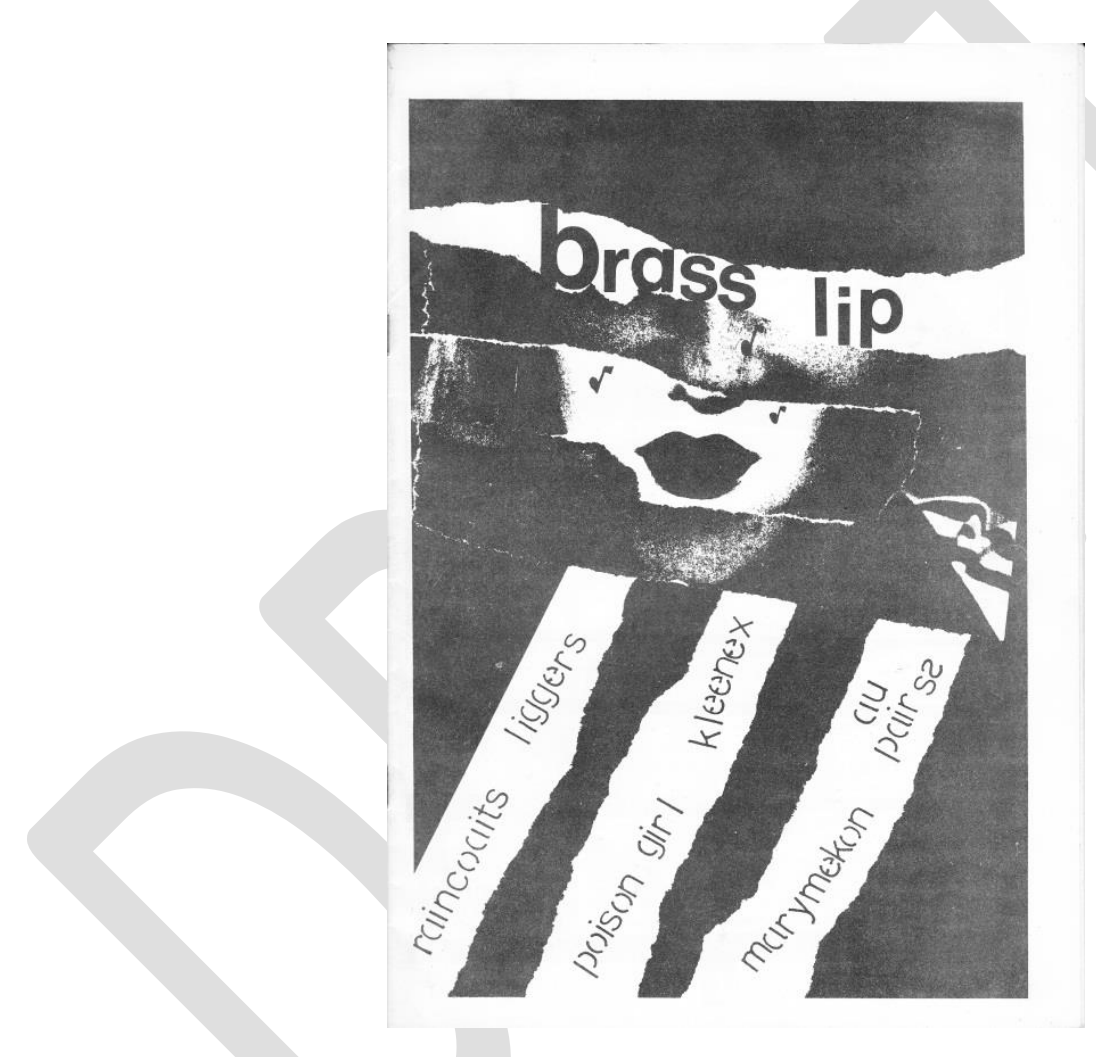

Perhaps the best example was Manchester's City Fun (1978-84), in which writers such as Andy Zero [Andy Waide], Liz Naylor and Cath Carroll combined irreverent humour with critical analyses that covered the broad contours of the new and libertarian left. ${ }^{72}$ Articles on RAR, CND and the city's gay scene sat next to barbed commentaries on Factory

\footnotetext{
${ }^{70}$ Brass Lip, No. 1, 1979. See, especially, the essay 'Roxex' (pp. 16-17), which takes as its starting point the advert for the Rolling Stones' Black and Blue album.

${ }^{71}$ Lucy Toothpaste, 'Sex \& Violence \& Rock \& Roll', Drastic Measures, No. 3, 1980, pp. 6-7; idem, 'Sex Vs Fascism', Temporary Hoarding, No. 7, 1978, pp. 4-6.

72 David Wilkinson, 'Difficult Fun: British Post-Punk and the Libertarian Left on the cusp of Neoliberalism, 197883', unpublished PhD thesis, University of Manchester, 2013.
} 
Records or Paul Morley's postmodern pretensions in the NME, while anti-consumerist critiques fed into amusing TV columns and media reviews. The mood could shift from the dogmatic - 'This society is based on hierarchy and exploitation. This is reflected in our relationships with others. Discrimination takes place at a pre-conscious level ${ }^{73}-$ to the satirical, as in Ray Lowry's regular cartoons. But underpinning it all was a critical sensibility informed by the leftist impulses of the time: towards feelings, desire and cultural expression that might point the way beyond the confines of patriarchy, the state or the market.

Finally, and more generally, the fanzines inspired by punk opened-up spaces of enquiry that provided outlets for creativity, intellectual exploration and political experimentation. This could take a variety of forms, be it collections of artwork (The Eklektik), homages to Wyndham Lewis' Blast! (Dat Sun), essays on urban living that drew from situationist influence (Adventures in Reality), or introductions to the likes of Wilhelm Reich, Henry Miller and Austin Osman Spare (White Stuff). ${ }^{74}$ For fanzines related to or informed by the industrial culture around Throbbing Gristle, attention centred on systems of control and the darker corners of the human condition: murder, fetishism and the abject. ${ }^{75}$ An interest in Aleister Crowley and the occult was also evident by the early 1980s, as were references to William Burroughs, Brion Gysin and other underground writers/artists. ${ }^{76}$ Occasionally, too, reading lists and book reviews were offered, with texts such as Stuart Christie and Albert Meltzer's The Floodgates of Anarchy (1970), Germaine Greer's The Female Eunuch (1970), Ursula le Guin's The Dispossessed (1974), William Morris' News from

\footnotetext{
73 'A Breakdown of Oppression', City Fun, No. 12, 1981, p. 6.

74 The Eklektik, No. 21982 (produced by Andy Palmer of Crass); Dat Sun, No. 1, 1978; Adventures in Reality, Issue G, 1981; White Stuff, Nos. 4 and 6, 1977.

${ }^{75} \mathrm{See}$, for example, 'zines such as, Flowmotion, Industrial News, Intolerance, Kata and Stabmental.

${ }^{76}$ See, for example, All the Madmen, Concrete Beaches, Kick and Rapid Eye Movement.
} 
Nowhere (1890) and Raoul Vaneigem's The Politics of Everyday Life (1967) being cited as points of reference for the aspiring punk activist. ${ }^{77}$

Taken altogether, and befitting punk's youthful demographic, the fanzines produced into the 1980 s revealed a vibrant, reflexive and sometimes crude (cultural) politics. Though their authors, subjects and readership claimed to recognize the limitations of punk's providing a medium for social or political change, they sought solutions either by exerting control over the punk and 'post-punk' cultures of which fanzines were part or by extending punk's protest beyond the commodified parameters of youth culture. This, occasionally, led to or complemented engagement with organized political movements and campaigns. Increasingly, however, punk's cultural politics began to shun the dichotomies of 'left' and 'right' in favour of an explicitly anarchist tendency alive to the fallacies of the media spectacle and set against the defined contours of state and society. In the words of Kill Your Pet Puppy's Tony Drayton:

Anarchy gives people back their self-respect, their PERSONAL IDENTITY, but to do so it has to destroy the false, national gods and institutions that have stolen your individualities and forced you to be slaves to their alters [...] The whole MYTH of society is breaking down, break down with it or help smash it into irrelevance. The capitalist concepts are obsolete [...] when an individual confronts the system with its own irrelevance it is an anarchistic act [ ...] 'Punk' exposes the myth-punks are the frontline, the shock troops that herald the collapse of the MYTH, the DEATH of a civilisation that ruled by fear of DEATH. Punks [sic] one and only message, one and

\footnotetext{
${ }^{77}$ And Don't Run Away You Punk, No. 1, 1984; Incendiary, No. 1, 1984; Kill Your Pet Puppy, No. 4, 1981.
} 


\section{The Impossible Dream ... ${ }^{79}$}

British punk's relationship to anarchy can be traced back to its origins. ${ }^{80}$ That said, the Sex Pistols' call to arms, 'Anarchy in the UK', initially served more as a signal of intent than a commitment to any political creed. For all his and Jamie Reid's prior connections to King Mob, McLaren was in thrall to the disruptive thrill suggested by anarchy rather than its ideological underpinning. Talking to the NME in 1976, he stated that: 'I just see it [anarchy] as a reaction against the last five years of stagnation [...] a statement of self-rule, of ultimate independence, of do-it-yourself'. ${ }^{81}$ Johnny Rotten [John Lydon] wanted to 'be' anarchy; to embody it rather than pursue it as a political aim in itself. Crass, however, adopted the term more decisively, using it to forge a recognizable alternative to the Sex Pistols' warning of a future measured only by shopping schemes, council tenancies and atrophy. ${ }^{82}$

This took time. Like the Sex Pistols, Crass (who formed in 1977 and released their first record at the end of 1978) initially used the term 'anarchy' and the anarchy symbol of a circled ' $A$ ' as part of an evolving linguistic and semiotic arsenal designed to provoke and disrupt. In Crass' case, this included the peace emblem associated with CND, all-black

\footnotetext{
${ }^{78}$ Tony Puppy, 'Apocalypse Now, Part 1', Kill Your Pet Puppy, No. 2, 1980, pp. 4-6.

${ }^{79}$ The heading is taken from the fanzine produced by the Poison Girls.

$80 \mathrm{Jim}$ Donaghey, 'Bakunin Brand Vodka: An Exploration into Anarchist-Punk and Punk-Anarchism', Anarchist Developments in Cultural Studies, 1, 2013, pp. 138-70.

${ }^{81}$ Nick Kent, 'Meet the Col. Tom Parker of the Blank Generation', NME, 27 November 1976, pp. 26-7. For McLaren and Reid's relationship to King Mob see David and Stuart Wise, 'The End of Music', in Stewart Home (Ed.), What is Situationism? A Reader, Edinburgh: AK Press, 1996, pp. 63-102.

82 Penny Rimbaud, 'The Last of the Hippies - An Hysterical Romance', in Crass, A Series of Shock Slogans and Mindless Totem Tantrums. London: Existential Press, 1982; Richard Cross, 'The Hippies Now Wear Black: Crass and the Anarcho-Punk Movement, 1977-84', Socialist History, 26, 2004, 25-44; George Berger, The Story of Crass, London: Omnibus, 2006.
} 
militaristic stage apparel, references to nihilism and existentialism, slogans declaring 'Fight War Not Wars' or 'There is no Authority but Yourself', and a distinctive motif that seemed to comprise a mesh of cross, swastika and union jack. ${ }^{83}$ Such ambiguities - clashing symbols were very much part of Crass' early aesthetic, serving to obscure or nullify received meaning in order to incite questioning as to the nature of power and its dissemination. By 1979, however, their strategy had led to the band's being courted and attacked by factions on both the political left and right, prompting a more assertive association with anarchy as a pathway beyond established political binaries. 'Boring fucking politics that'll get us all shot', Steve Ignorant [Steve Williams] sang on the band's Stations of the Crass album (1979), 'left wing, right wing, you can stuff the lot [...] Anarchy and freedom is what I want' ${ }^{84}$ To this end, the band lived collectively in Dial House on the edge of Epping Forest and cultivated a creative hub that inspired countless bands, records labels and political initiatives to unfold over the 1980s and exist outside the prevailing structures of the music industry and society more generally. ${ }^{85}$

Not surprisingly, Crass' influence soon became evident in punk fanzines. The band's approach fitted perfectly into the DIY ethos of the culture, while their uncompromising sound, look and lyrics resonated with those who took the radical implications of punk's emergence seriously. Already, discussion as to punk's political meaning had found its way into some early punk 'zines. ${ }^{86}$ In the wake of Crass, whose record sleeves opened out to reveal articulate dissections of religion, geo-politics and social relations, and whose

\footnotetext{
${ }^{83}$ The emblem was designed by Dave King to represent various forms of repression. The symbol is enveloped by snakes eating their own tails.

84 'White Punks on Hope', Stations of the Crass, Crass Records, 1979.

${ }^{85}$ Ian Glasper, The Day the Country Died: A History of Anarcho Punk, 1980-84, London: Cherry Red, 2006. Dial House had existed as a collective and creative space long before 1977.

${ }^{86}$ 'Punk and Politics', Ability Stinks, No. 1, 1981 , p. 6; 'Posh or Poor', City Chains, No. 2, 1977, p. 10; 'Marxism and the Mass Media', Jolt, No. 2, 1977, p. 5; Plaything, No. 2, 1977, p. 1.
} 
International Anthem provided a template for combining visual and textual assaults against 'the system', so debate extended beyond the realm of creative expression. Toxic Graffitti, for example, produced by Mike Diboll, featured band interviews alongside politicallycharged collage, treatises on anarchy and diatribes against state repression (see figure 7). By issue five (1980), known as the 'mental liberation issue', the music coverage was all but subsumed within a series of nihilistic ruminations on the inanity of work, the illusion of politics and the stifling abjection of everyday life.

God is a lie. There is no god, god is a con-trick, death is oblivion ... I reject religion, I reject work, in a system of capitalism (or state capitalism, as in fascism, or communism, the same thing) ... work is slavery, it never sets you free, that's a fucking lie, the 'myth' of capital ... yes, I reject contemporary values and past values ... I see no political solution, for politics left or right is lies ... REALIZE THE INSANITY OF 'CIVILIZATION' AND ITS STINKING OVERKILL, OVEREAT, OVER EVERY FUCKING THING, THEN ACT TO DESTROY IT. ${ }^{87}$

\footnotetext{
${ }^{87}$ Mike Diboll, 'The Admition', Toxic Grafity, No. 5, 1980, p. 18. Issue number ' 5 ' seems actually to have been the third issue of the fanzine. It had previously been titled No Real Reason.
} 


\section{Toxic $g i(A)$ it}

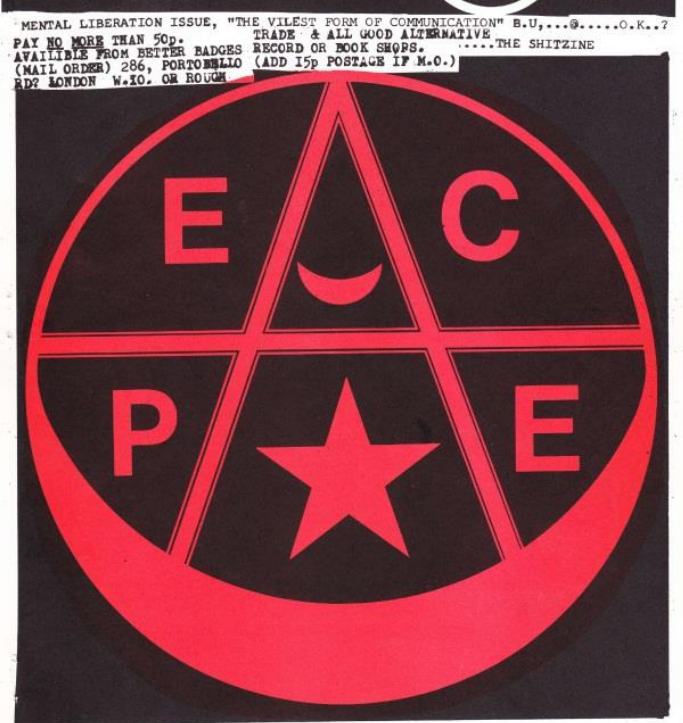

A REality OFHORROR

Forming the stereotype. .

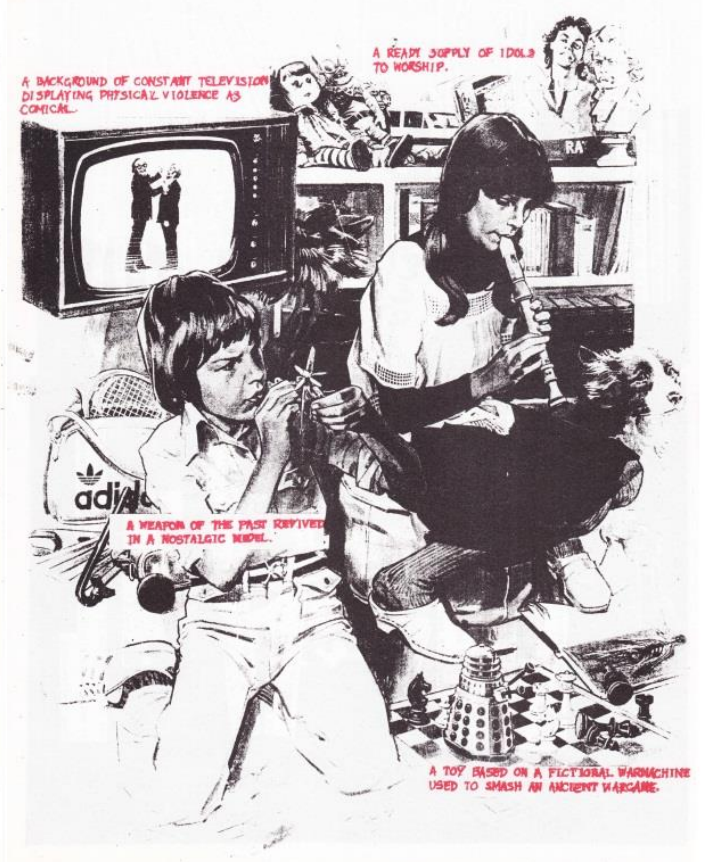

LABELS Just FUckING SegREG ate/D] VIDE/UP the people an CReaTE BULI $\oplus$ SHIT and Du\|ACCePIJa NGE or VIOLE ce ... Ja
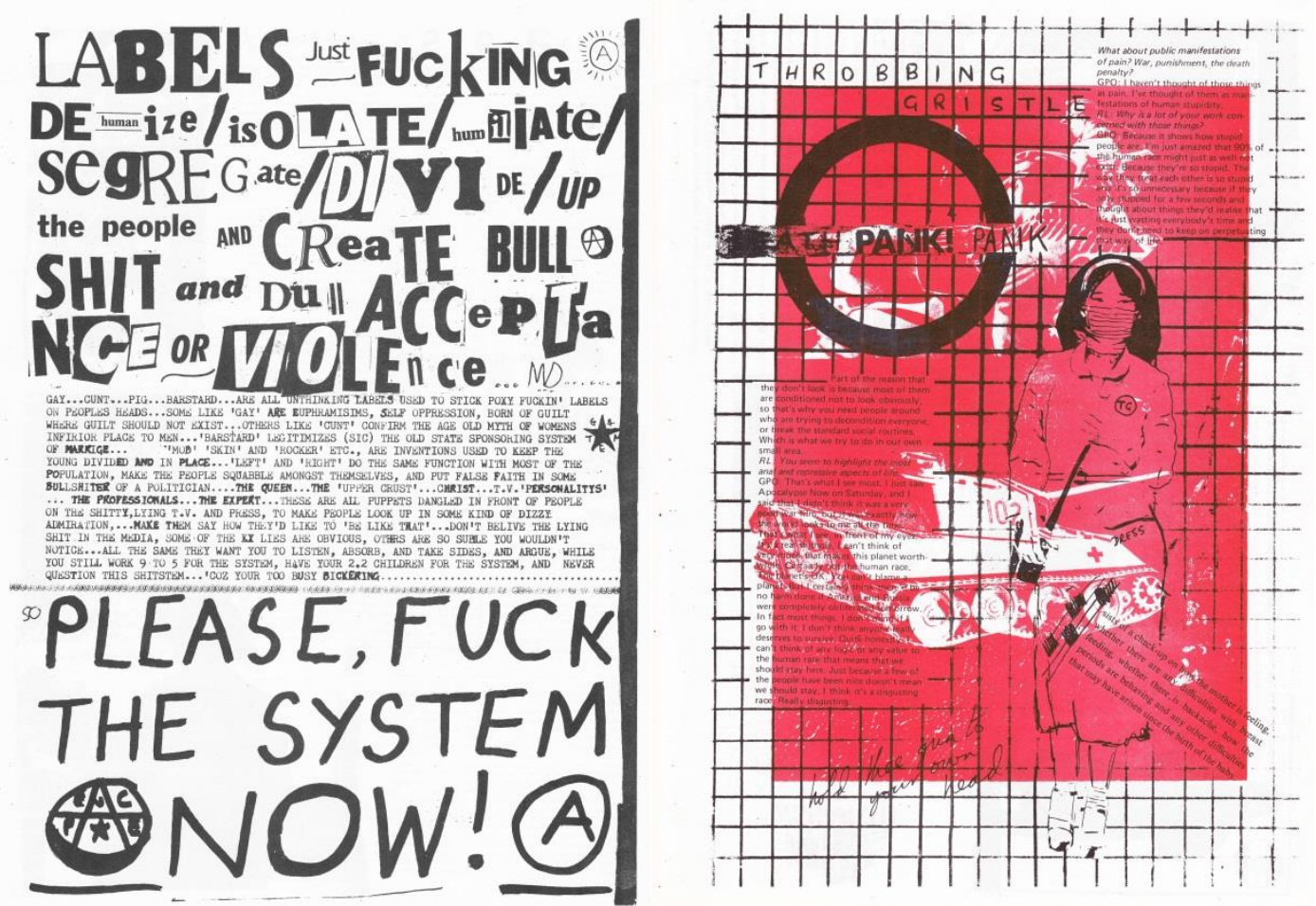

Others followed suit. Cobalt Hate emerged from Stevenage in 1979 as a scrawled mess of slogans, rants and cut-up media text - the third issue of which came under a strapline of 'anarchy, heresy, nihilism, contempt' (see figure 8). Among those gathered in 
and around the Autonomy Centre set up in London's Wapping area in 1981-82 and the Centro Iberico (1982) in Westbourne Park, 'zines such as Book of Revelations, Enigma, Paroxysm Fear, Pigs for Slaughter, Precautions Essentieiles Pour La Bonne and Scum provided hardline anarchist essays that urged direct action against property, fascist groups and the state. Guides to graffiti and the effects of CS gas were offered, drawing from a classconscious interpretation of anarchy that later fed into the Class War initiatives of the mid1980s. ${ }^{88}$ More esoterically, those involved in the Kick and Kill Your Pet Puppy collectives began to conceive a punk-inflected anarchy centred on 'beating reality rather than escaping it'. This, Richard Cabut wrote between 1980 and 1982, suggested an anarchism that was more of a 'mystic affair than a political one', revolving around an 'experiment in life' that comprised squatting (or housing co-ops), creativity and resistance to the 'conventions and expectations of society'. ${ }^{89}$

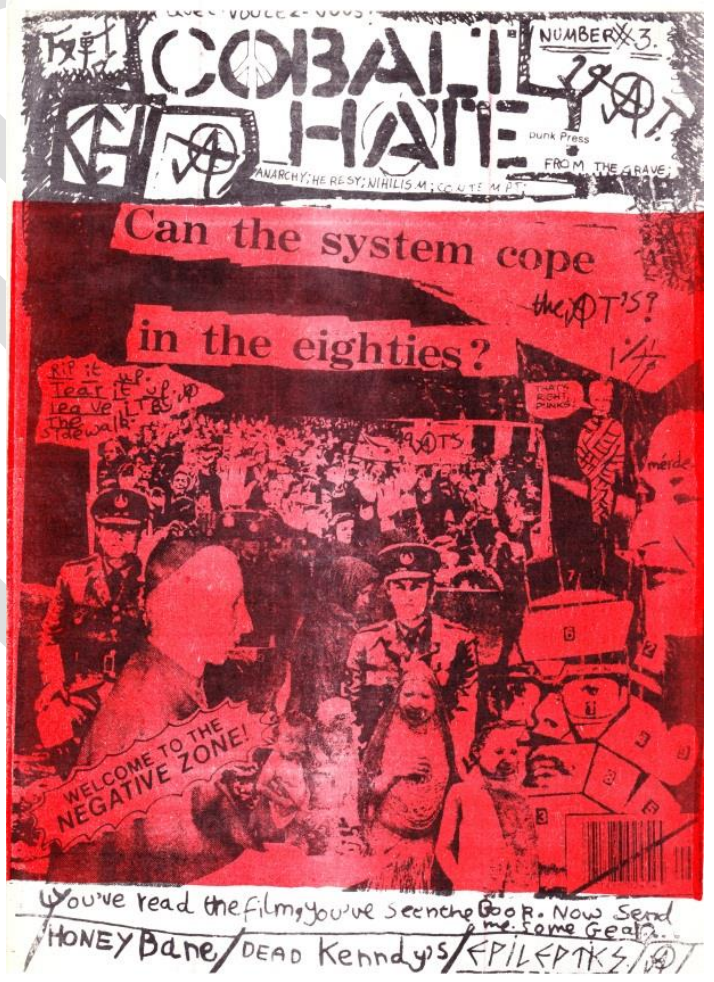

\footnotetext{
${ }^{88}$ Class War, A Decade of Disorder, London: Verso, 1991.

${ }^{89}$ Quotes taken from Kick, Nos. 3 and 4, 1980-82. See also All the Madmen and And Don't Run Away You Punk.
} 
Such debate led to serious disagreement between those who perceived anarchy as a 'state of mind' (a revolution that began and ended with the individual) and those who envisaged a collective movement committed to smashing the state. Not dissimilarly, discussion ensued between those who took a pacifist position and those who advocated a politics of physical confrontation. ${ }^{90}$ There developed simultaneously, however, a relatively coherent ideological foundation to punk's DIY anarchism. Religion was recognized as an archaic root of oppression, a moral and institutional construct deployed historically to protect ruling elites by mentally, emotionally and physically enslaving those over whom they governed. The state, meanwhile, was presented as an apparatus of repression that wielded power in defence of vested interests (politicians, the owners of capital); its forces - the police, military and law courts - were utilized to control, suppress and, where necessary, destroy all vestige of resistance. The media, of course, served as an opiate for the masses and a means of indoctrination. At the social level, too, the family existed as a site of conditioning through which gender roles, patriarchy and hegemonic values were imposed and further reinforced via the education system. The interests of capital were serviced through the exploitation of science and a war machine that projected the threat of nuclear holocaust to both terrorize and subjugate; the cold war was a power-play of two elite systems engaged in a destructive endgame. From a British perspective, Margaret Thatcher became the icon of state oppression: the instigator of war (The Falklands) and the public persona of a system willing to crush those seeking to exist outside or challenge her vision of Britain's 'new beginning' (see figure 9$).{ }^{91}$

\footnotetext{
90 Richard Cross, 'British Anarchism and the End of Thatcherism', in Evan Smith and Matthew Worley (eds), Against the Grain: The Far Left in British Politics, Manchester: Manchester University Press, 2014. Also, compare 'zines such as Fack and Toxic Graffitti to Andy Martin's Scum or lan Rawes' Pigs for Slaughter.

${ }^{91}$ This was the term used in the 1979 Conservative Party manifesto.
} 


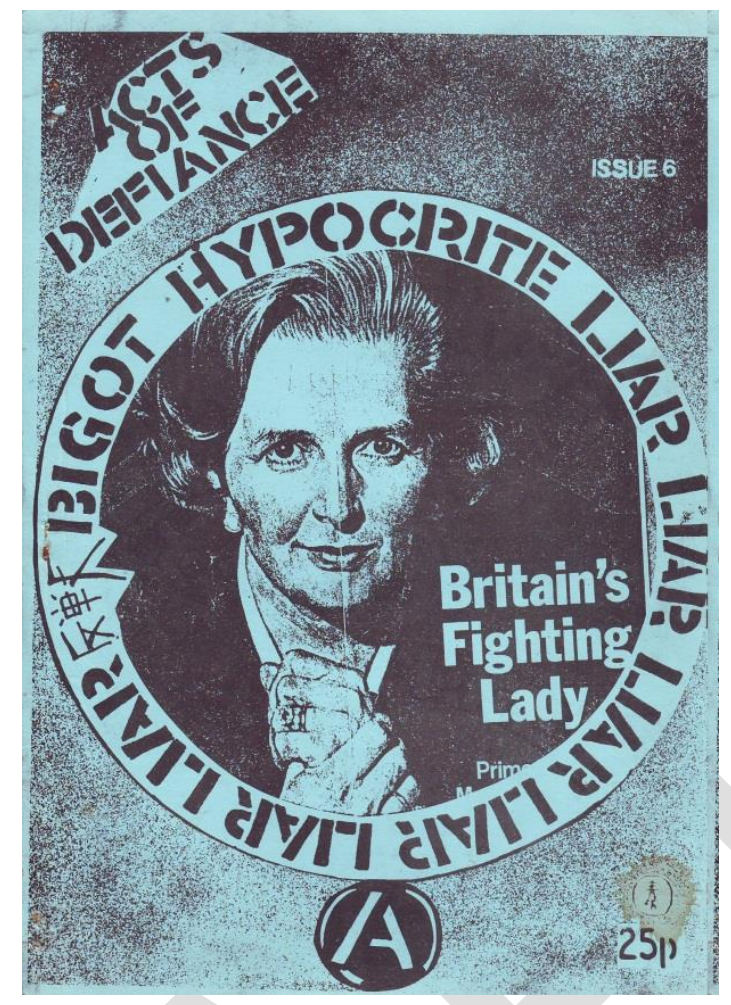

Consequently, by the early 1980 s, there existed countless 'zines keen to combine politically-charged interviews with fierce condemnations of the war state and its various adjuncts. ${ }^{92}$ In effect, punk's cut ' $n$ ' paste approach was refracted through a dystopian lens: images of nuclear mushroom clouds, tortured animals and starving children segued into polemics designed to puncture the 'reality' constructed by politicians and media simulacra. Or, as described by Anathema (1982), 'Your future is in the hands of someone else. Hands now tied by financial bounds. Mind controlled with chains of language and a lack of ideals. Always taking the easy way out [...] Authority is authority, power is power [...] To rule you need power. To have power you must keep it [...] Make promises, lie to them/us, smile

\footnotetext{
${ }^{92}$ A few examples would include A New Body (Peterborough), A System Partly Revealed (London), Bring into Being (Rocester), Coming Attack (Leighton Buzzard), Fack (North Cheam), Fight Back (Blackburn), Guilty of What (Stirlingshire), New Crimes (Southend), Nihilist Vices (London), Re-Action (Welwyn Garden City), Scrobe (Whitehaven) and Twisted Nerve (Meriden).
} 
profit [...] Time for dinner, turn on the radio. Oh no, third world's dim light is almost out. Fourth Reich is rising fast on a tide of public unrest' ${ }^{93}$

Yet, the importance of these 'zines related as much to their establishing networks of young punk activists as it did to developing a recognizably anarchist politics. Integral to punk was its means to agency, and this extended to the political realm once anarchy was adopted as more than just a symbol of self-expression. Thus, if we take a selection of the anarchist 'zines produced in the north east as an example, we find trace of a politically-engaged milieu seeking to transfer theory into practice. ${ }^{94}$ Alongside discussion as to the practical and intellectual limits of anarchy, links are revealed to local action groups (Sunderland Anti-War group, Tyne \& Wear anarchists, anti-fascist cells), anarchist bookshops (Red and Black in Middlesbrough) and national movements including CND, the Animal Liberation Front (ALF) and the Hunt Saboteurs Association. Essays on the women's movement give way to debate as to the effectiveness of CND demonstrations or the ramifications of the Falklands War and the miners' strike. In addition, those involved formed part of local musicians' collectives that set up venues such as The Bunker in Sunderland to host benefit gigs, rehearsals and provide room for political and community groups to meet. At the grass-roots, then, punk's fanzines bled into an oppositional and politically-active culture some way removed from the transitory delights of the pop chart or the vagaries of youth cultural style.

The anarchism articulated through punk fanzines bore a contentious relationship to previous traditions of anarchist thought, even as it mirrored many of its historic tensions. ${ }^{95}$

\footnotetext{
93 “Life Today ... Is It Really Life?', Anathema, No. 1, 1982, pp. 17-18. Anathema was produced by Lee Gibson, who changed the name of his 'zines frequently. Other titles included Protesting Children Minus the Bondage and Kiss the Earth. See Lee Gibson, A Punk Rock Flashback, London: Lulu, 2013.

${ }^{94}$ Titles from the region include Acts of Defiance, Anathema, A Trip into Realism, Cardboard Theatre, Hate and War, IQ32, No Comment and Testament of Reality.

95 Richard Cross, "There is No Authority But Yourself": The Individual and the Collective in British AnarchoPunk', Music and Politics, Vol. 4, No. 2, 2010.
} 
It was, in many ways, an anarchism forged from a variety of impulses, be they realignments on the left occasioned by the advent of new social movements and the prevailing influence of the sixties counter-culture or an inverse response to the socio-economic, cultural and technological changes of the late twentieth century. Here was an emphasis on individuality and freedom at odds with the rhetoric of the New Right but equally scathing of communism and the social-democratic left. ${ }^{96}$ Because of this, perhaps, the anarchism proffered through punk's fanzines could be dogmatic and insightful, idealistic and proscriptive. A misanthropic tone ran through some of the fanzines' text, revealing a disdain for 'ordinary' people or the uncommitted that suggested an elitism as dour as it was smug. ${ }^{97}$ Nevertheless, the 'zines formed part of a broader anarchist movement that bolstered the ranks of CND, brought animal rights' activism into the public domain and rendered a significant enough presence to excite condemnation in parliament and attention from the police. ${ }^{98}$ If the Battle of Beanfield (1985) was the most vicious response to the traveller culture that bore roots in punk's anarchism, then the Stop the City protests organized in 1983-4 served as part of a continuum that leads to the anti-globalization and anti-capitalist demonstrations of more recent times. ${ }^{99}$

\footnotetext{
${ }^{96}$ For criticism of the left, including such initiatives as RAR, see 'Fascists - What Next?', Toxic Graffitti, No. 3, 1979 , p. 3, following on from Crass' condemnation of the political left as printed in Kill Your Pet Puppy, No. 1, 1980, pp. 13-15. See also, New Crimes, No. 4, 1981, pp. 10-11.

${ }^{97}$ For a critique of these attitudes, see Tom Vague, 'Those Not So Loveable Spikey Tops', Vague, No. 14, 1983, p. 29.

${ }^{98}$ A local example would include the police raid on the Freewheel bookshop in Norwich, during which copies of the fanzine Final Straw were seized on account of an article demonstrating how to prepare petrol bombs.

99 Andy Worthington (Ed.), The Battle of the Beanfield, London: Enabler Publications, 2005; Kevin Hetherington, New Age Travellers: Vanloads of Uproarious Humanity, London: Bloomsbury, 2000; George McKay, Senseless Acts of Beauty: Cultures of Resistance since the Sixties, London: Verso, 1996.
} 


\section{'I don't like fanzines anyway, they're boring and unconstructive, but it's better than} reading The Sun ${ }^{100}$

The anarchist 'zines of the early 1980s were perhaps the closest punk came to producing the catalogue of radical, 'pro-situ' pamphlets evoked by Jon Savage. Not only did the spirit of ranters such as Abiezer Coppe ripple through the centuries to find vent in the writings of Mike Diboll, Lee Gibson, Andy Martin, Jah Ovjam (Graham Burnett), lan Slaughter (Ian Rawes) and others, but the libertarian politics of the sixties counter-culture were diverted from the utopian panoramas of hippiedom towards the bleak vistas of a punk culture enveloped by economic depression, heightened geo-political tensions and the blunt trauma inflicted by Thatcherism on the British body politic. ${ }^{101}$ In between, the cultural spaces opened up by punk provided for fanzines of diverse quality and style. Some - perhaps most - focused primarily on music, holding fast to punk's urge to reclaim rock ' $n$ ' roll for the young people who made and listened it. ${ }^{102}$ Others expanded the fanzine template to incorporate collage, poems and short stories; many, too, engaged with the prevailing themes of the day: alienation, consumerism, drugs and glue, sexual politics, the distorting lens of the mass media, racial tensions, youth cultural violence and the impending threat of nuclear war. In all cases, the politics of fanzine culture were located as much in the mode of production as their content.

From a historical perspective, punk fanzines offer a snapshot of the interests, concerns and opinions of a significant milieu of British youth in a period of notable socio-

\footnotetext{
${ }^{100}$ Bondage, No. 1, 1976, p. 6.

101 Andrew Hopton (Ed.), Selected Writings: Abiezer Coppe, London: Aporia Press, 1987; Jerome Friedman, Blasphemy, Immorality and Anarchy: Ranters and the English Revolution, Ohio: Ohio University Press, 1987; Christopher Hill, The World Turned Upside Down: Radical Ideas during the English Revolution, London: Penguin, 1991, originally published 1972. Graham Burnett wrote the New Crimes 'zine.

102 This remained true even as punk evolved and new or revived music styles and genres developed in its wake. See, for example, Maximum Speed (Mod) or Are You Scared to Get Happy? (C86), with its strapline: 'Getting back to basics ... a punk rock fanzine'. See Pete Dale, Anyone Can Do It: Empowerment, Tradition and the Punk Underground, Farnham: Ashgate, 2012, pp. 150-1.
} 
economic, cultural and political change. Culturally, they reveal the shifting parameters of the musical and stylistic forms that emerged in and around British punk over the late 1970s into the 1980s and beyond. Crucially, too, they demonstrate the extent to which (youth) cultures are not simply produced and consumed but constructed and utilized. The fanzines that first emerged in lieu of informed media coverage soon cultivated their own narratives and interpretations of punk's meaning and development, many of which existed some way (geographically and culturally) from the hub-bub of London. ${ }^{103}$ Conversely, fanzines enabled access to the established culture industry, providing a 'way in' to journalism or the music industry for those who wished to pursue it. ${ }^{104}$

Politically, fanzines provided opportunity for opinions to be espoused and ideas explored. By so doing, they opened up an alternative space for young people estranged from or denied access to existent political realms. This was taken to a glorious extreme in the anarchist 'zines, but the cultural critiques offered by City Fun and Jolt, or the antiThatcherite diatribes of the poet ranters, serve to remind us of a vibrant leftist milieu struggling to make sense of a shifting political terrain. Arguably, of course, the gender politics and disavowals of racism featured in several punk fanzines were as integral a part of the socio-cultural changes affected over the 1970s and 1980s as the economic and political transformations initiated by government and capital. Simultaneously, the adoption of an anarchist identity across a significant strand of punk culture may be seen as symptomatic of a more general disengagement from mainstream or traditional politics. Certainly, punk

\footnotetext{
${ }^{103}$ There are echoes here of the ideas developed from Jürgen Habermas' concept of the public sphere, especially with regard to Nancy Fraser, 'Rethinking the Public Sphere: A Contribution to the Critique of Actually Existing Democracy", Social Text, 25-26, 1990, pp. 56-80. Thus fanzines may be seen to have helped punks form a 'subaltern counterpublic' committed to formulating alternate and sometimes oppositional 'interpretations of their identities, interests and needs' (p. 67). See also Michael Warner, Public and Counterpublics, Brooklyn: MIT Press, 2009.

${ }^{104}$ Garry Bushell (Napalm), Cath Carroll (City Fun), Steve Lamacq (A Pack of Lies), Gavin Martin (Alternative Ulster), Paul Morley (Girl Trouble), (Sandy Robertson (White Stuff), Jon Savage (London's Outrage), Adrian Thrills (48 Thrills) and Johnny Waller (Kingdom Come) are just a handful of examples.
} 
'zines (and most punk bands) tended to eschew political affiliation; subcultures and popular music were embraced as an alternative to - or a diversion from - a world of mundane work/school, staid relationships, inane media distractions and the distant squabbles of a seemingly entrenched political elite. For this reason, perhaps, even those attempts by organizations on the political left and right to exploit and direct punk's apparent dissatisfaction brought only scant reward. Punk's abiding impulse was to 'do it yourself', not conform to the diktats and doctrines of self-appointed ideologues.

Ultimately, punk fanzines served as a product of agency, a means of participation and a platform for creative and political expression. They could be insular and elitist, repetitive and simplistic, puerile and naïve. But the best took up punk's cultural critique to provide an alternative press alive to the fallacies of media representation and free from the demands of the marketplace. In the process of their production and formative political expression, fanzines embodied punk's DIY spirit and call to action. They cultivated an alternative space to engage with or voice estrangement from more formal political mechanisms and ideas. Looking back on them now, they appear a mix of youthful exuberance and engrained disaffection - the product of a generation whose future appeared overcast by uncertainty but whose culture was rich with possibilities. 